\title{
Gulf banks' public relations use of interactive communication with customers
}

\author{
Dr. Abdulsadek Hasan* \\ Dr. Faheema Abdullah **
}

\begin{abstract}
The study aimed to investigate the websites role in communicating with banks customers in the Kingdom of Bahrain, and its efficiency in carrying out banks' duties and responsibilities towards customers by identifying the contents that customers preferred to follow on the Bahraini banks' websites and weaknesses of these sites. The study used the survey method and depended on a simple random sample. A total of 300 questionnaires were distributed to gather information from Bahrain's commercial and Islamic banks' customers, after excluding questionnaires that did not include answers to all questions, the study sample included 241 customers (137 of commercial banks and 104 of Islamic banks).
\end{abstract}

\section{Results of the study:}

- Commercial and Islamic banks relied on e-mail and SMS to contact with customers.

- Bahraini banks are concerned with contents regarding: activities provided by the bank and the leading figures, how to conduct business transactions, investment opportunities and savings, periodical and annual reports issued by the bank and the bank phone numbers and e-mail. The study shows that commercial banks was superior to Islamic ones in concerning with information about the bank's services, the bank' role in society, the bank's leading figures, and investment opportunities.

- More than half of the respondents said that the website of the banks responded to their inquiries within two weeks, and there are no statistically significant differences between commercial

* Associate Professor of Public Relations and Advertising, Ahlia University -

Kingdom of Bahrain

** Assistant Professor of Public Relations, Ahlia University - Kingdom of Bahrain 
and Islamic banks according to the duration in which Bahraini banks responded to customers' complaints and inquiries.

- The e-mail ranked first in customers interaction with the Bahraini banks' website, then links to additional information, the participation of topics via social networking sites ranked third, followed by printing data provided on the site, then downloading files, and direct chatting cams in last

- The results of tasting hypothesis confirmed a correlation between the extent to which the public relations departments in Bahraini banks updated the banks' websites and customers' attitudes towards the importance of these websites. Also, it proved a positive correlation between the weaknesses of the Bahraini banks' websites and customers' attitudes towards the importance of these websites. In addition to a positive correlation between the extent to which Bahraini banks' managements updated the banks' websites and customers' attitudes towards the importance of these websites. 


\section{ملخص الاراسة}

هدفت الدراسة إلى التعرف على دور المواقع الإلكترونية في التواصل مع فئل عملاء

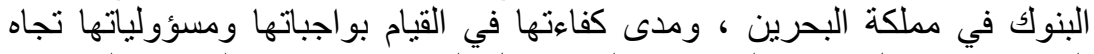

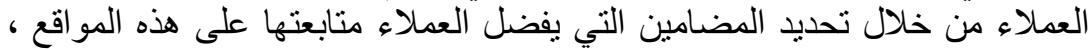

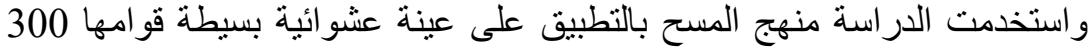

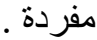

$$
\text { وتوصلت الدراسة إلى العديد من النتائج ، من أهمها: }
$$

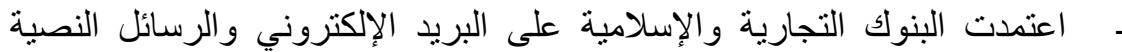

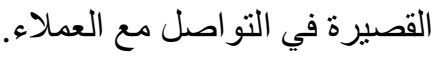

ـ ـ ـ اهتم الموقع الإكتروني للبنوك البحرينية بالمضامين التالية: الأنشطة التي يقدمها

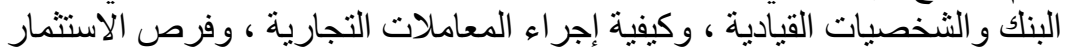

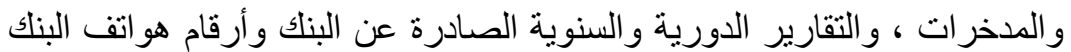

$$
\text { والبريد الإلكتروني. }
$$

- - أظهرت الدراسة تفوق البنوك التجارية على البنوك الإسلامية فيما يتعلق

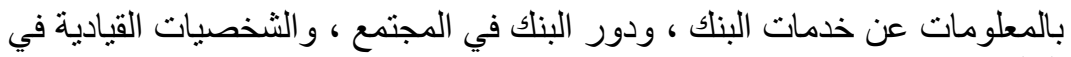

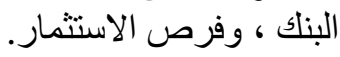

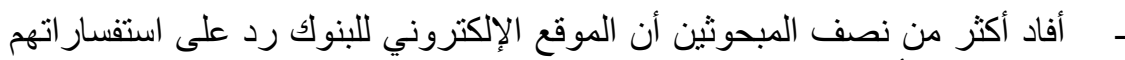

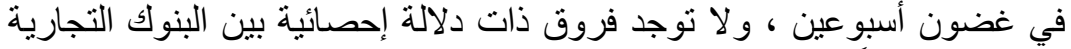

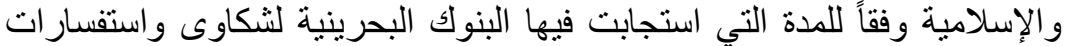

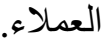

كثفت نتائج الدراسة أن البريد الإلكتروني احتل المرتبة الأولى في تفاعل العملاء

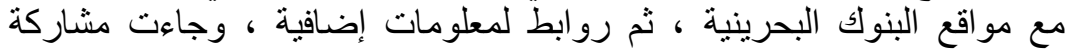

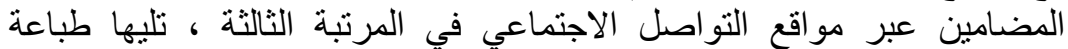

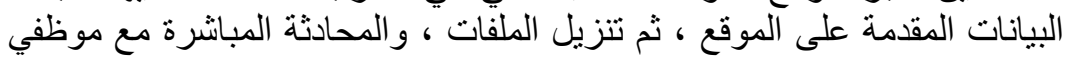

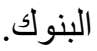

كثف اختبار فروض الدراسة عن وجود علاقة بين مدى تحديث إدار ات العلاقات

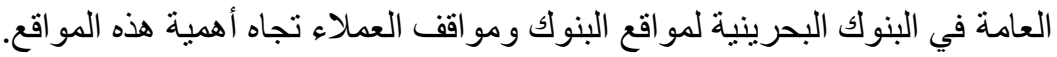

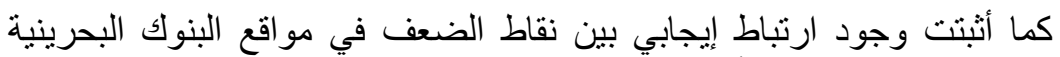

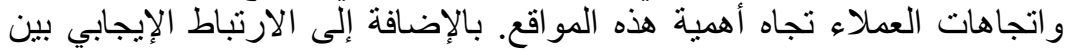

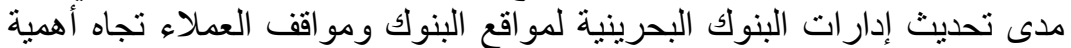

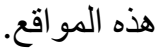




\section{Introduction:}

The importance of websites has been grown in banks as a result of technological, political and economic implications. These websites have become the link between the bank and its internal and external customers. They provide a specific service based on the mutual trust between banks and their customers.

These websites have a great role in the organizational structure of various financial and banking organizations because they can help these organizations to implement their different roles, especially the rapid reaction with customers to gain their support.

Organizations succeed by achieving their goals which are arising from customers' goals. The organization can make success in communicating its customers by knowing their expectations. Even though the organization pays attention to customers' strategic interests, it must change its goals over time to be more effective and more compatible with public needs.

It's well known that the role of websites in an organization aims to inform the public with honest information and facts about its activities to maintain a positive image and reputation of the organization.

Also, websites aim to develop good relations among the employees on one hand and between the employees and the senior management on the other hand. This leads to create a spirit of partnership and solidarity which leads to solve employees' problems quickly, and raise the production efficiency, which is directly related to the quality of products or services, as well as the economic or social activity of the organization.

In banks, the website offers many services to the external customers. It creates an efficient and open communication with them, which helps significantly in changing the stereotype image of public relations departments in dealing with customers, as well as in facing various crises. It also helps in distributing information about the organization easily and quickly. In addition to that, it can play a role in delivering the bank's message to customers through a two-way communication ${ }^{(\mathbf{1})}$.

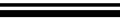


Banks are one of the essential pillars of the state economies, because they play an important and effective role in developing the economic situation. They connect economic processes and commercial deals together in order to activate all sectors contributing in building the state economy.

Today, the banks are necessarily needed. They have to improve their administrative efficiency to achieve their goals and strategies, this requires activating their communicative role by using all communicating forms and patterns to contact their customers.

Research on Bahraini banks websites takes on special importance due to the contemporary responsibilities and practices of these sites. There is an academic research interest aims to adapt these websites goals and communication policies with the general goals of their banks. It also aims to measure the ability of these websites to do their duties and communication responsibilities, especially achieving coordination at every level of management in order to achieve the organizational goal.

Banks, like any organization, cannot operate or survive without having an internal communication system between their employees. Also, banks need to connect with all customers, so public relation departments need to be in contact with these customers through websites in order to achieve the organization goals according to public interests.

Hence, the study seeks to identify Gulf banks' public relations departments use of interactive communication with customers applying to Bahraini commercial and Islamic banks. It aims to determine how far customers use websites in dealing with these banks, their attitudes towards these websites and disadvantages of this use.

\section{Literature Review:}

The researcher describes the previous studies regarding communication process, public relations practice, and relationship between public relations and organizations work.

In order to examine how the communication of organization affects its relationship with customers, Reda Hani Abdel Ra'ouf's study (2018) $)^{(\mathbf{2})}$ aimed to analyze and evaluate the bank use of 
interactive communication through traditional and electronic channels in managing its relationship with customers and measuring the impact of this communication on this relationship indicators. Applying to a sample of 200 customers dealing with NCB and Credit Agricole Bank, the study found that sending letters by regular mail was the most traditional way of communicating with NCB customers, by (62.4\%). For Credit Agricole bank, personal contacting with the bank employees came at the first position $(61,3 \%)$. According to the two banks, the other traditional methods of communicating with customers were: landline contacting, bank publications, seminars, exhibitions and finally conferences. The results proved that sending messages to mobile phones was the most common method of communicating with customers in NCB and Credit Agricole Bank by (69.3\%) and (68.8\%) respectively. The Bank's Facebook page -as a modern way of communicating- $\mathrm{c}$ came at the last position for $\mathrm{NCB}$ and Credit Agricole bank by (2.4\%) and (1.3\%) respectively.

Focusing on attitudes of customers, Ro'aa Ali Youssef Ahmed's study (2017) ${ }^{(\mathbf{3})}$ aimed to identify the public relations role in improving customer attitudes towards banking services applying to Faisal Islamic Bank of Sudan 2015-2016. The study was conducted on a sample of 100 customers. Its results proved that attitudes of customers towards the banking services were improved when public relations department paid attention to their views and aspirations. This department followed the research system which tries to improve attitudes of customers towards banking services. Through these results, the study presented the following recommendations: The public relations department should respect the individual differences between customers in developing marketing and advertising policies (especially the gender and the special needs requirements), in addition to the different levels of education, employment, and individual income.

Concerning about customer's loyalty to the bank, Mohamed Shihada Ibrahim Al-Inizi's study (2016) ${ }^{(4)}$ aimed to identify the impact of Customer Relations Management "CRM" (which represents in: customer-orientation, modern communication "technology", customer data base, service quality, and good relationship with the customer) in achieving customers' loyalty to the commercial banks of Al-Zarqaa city. Applying to a sample of the commercial banks 
employees of this city, the study found that commercial banks in AlZarqaa city applied CRM rules. The good relationship with the customer came at the first position while the customer data base came at the last one. The commercial banks of Al-Zarqaa city achieved a high level of customers loyalty. The customer-orientation and the service quality had a statistically significant impact in achieving customers' loyalty. While the modern communication ways, the customer-orientation and the customer database had a poor statistical significant influence in achieving this loyalty.

Moreover, Farahat Mohammed Khalil's study (2016) ${ }^{(5)}$ aimed to identify the effectiveness of public relation communication at Libyan banks, by studying the internal and external communications carried out by public relations departments. The study community included (130803) bank customers and clients, (80525) from the National Commercial Bank and (50278) from the Trade and Development Bank. The stratified random sample and the complete census method were used. The results of the study found that $(66.7 \%)$ of the respondents believed that their public relations departments employed ICT at a medium level. Internet access came at the first position $(86.7 \%)$ as a modern communicating system. The study showed that the management of public relations in Libyan banks was dependent on means of communication by $(80 \%)$. The Internet came at the first position (93.3\%) as one of the most effective communication means used by the public relations departments in Libyan banks.

The main purpose of Firas Muslim Abuqaaod \& Imad Ahmed Aldheimat study (2016) ${ }^{(\mathbf{6})}$ was to identify the impact of e-marketing in achieving customers' satisfaction applying to the Commercial Bank of Jordan. The study aimed to evaluate the impact of e-marketing practiced by the Bank of Jordan in gaining customers' satisfaction rate by making its services available electronically, and providing electronic means of communication to contact customers (website, mobile phone and ATM). The study tried to reach to results that can help the Bank of Jordan -as well as other commercial banks- to gain their customers' satisfaction and ensure their loyalty, which may contribute to attract new customers and enhance the bank competitive position. The study adopted two main hypotheses that focused on the 
impact of e-marketing on the customers' satisfaction. The simple random sample is used to represent the entire data population. The sample included 340 clients. The study assured the effect of electronic marketing through electronic services in gaining customers' satisfaction of the bank. The effect of e-marketing on the satisfaction was significant due to the use of different electronic means of communication.

Focusing on Jordanian banks, So'oud Mohamed al- Mahamed (2014) $^{(7)}$ aimed in his study to identify the impact of the employees readiness to use electronic business system services on perceived quality and users satisfaction. Applying to a sample of 215 items, the study found that Jordanian banks employees had a high level of readiness to use e-business application systems. It assured the positive significant relationship between employees' readiness to use ebusiness application systems and each of perceived quality, user satisfaction and use intention. In addition, the results indicated that there were significant statistical differences in the employees evaluation for their readiness to use e-business application systems due to the level of education more than gender and experience years number.

To identify the role of Egyptian institutions websites design in supporting the communicative function of these institutions, Eman Hegazi (2013) ${ }^{(\mathbf{8 )}}$ analyzed these websites design of (Akhbar Al-Youm portal - Al shorouk portal - NBE - Société Générale - Al Mansoura University $-6^{\text {th }}$ October University) applying to a sample of 388 items, from April $1^{\text {st }} 2012$ till June $1^{\text {st }}$ 2012. The study assured that introducing these institutions through their websites was weak. The downloading of homepages was slow. The designs of websites were not compatible with the mobile phones and ipads. The design role in supporting the educational function was insufficient, as it only served a few educational goals, such as providing schedules of lectures and examinations. Also, its role in marketing was insufficient, because it was limited to display some services without marketing all products. While Akhbar Al-Youm \& Al- Shorouk websites concerned with the design which supportted the performance of communication function.

Regarding the crisis situation, study of Ahmed Radwan (2012) ${ }^{(\mathbf{9})}$ aimed to examine how institutions used websites and internet 
communication means in managing communications during facing a crises. By a case study of the Japanese company Toyota Auto industry crisis, the study found that Toyota used the interactive internet communications clearly through its website to communicate with customers. The company used strategies of apology and taking corrective measures to protect its reputation and image. Regarding its media online center, the company used many traditional and interactive messages to convey communicative messages which supported its strategies included press releases, video files, reports and live interviews.

In examining the new and tradition communication means used by organizations, Genilo $\mathbf{2 0 1 1}^{(\mathbf{1 0})}$ aimed to identify the use of public relation methods in Bangladesh. The researcher used the survey method and the content analysis tool to analyze content of 50 websites (20 websites of public sector companies, 20 of private sector companies, and 10 of investment sector). Also, the study used the electronic questionnaire tool applying to 50 public relation officers and consultants in these companies. The study assured using lot of communication means by public relations in dealing with the audience through the internet, these means were: newsletters (42\%), private events $(32 \%)$, annual reports (24\%), information of products $(29 \%)$, advertising (22\%), and customer service (19\%). The study added that the new means used by public relations to communicate with the audience through the internet were: e-mail (54\%), SMS (48\%), egroup (8\%), and e-video (22\%). While the traditional means determined in: newspapers $(90 \%)$, television $(86 \%)$, radio $(38 \%)$, movies (24\%), advertising boards (40\%), telephony (50\%), road advertising (10\%), sale stalls (10\%), and sale signs (24\%).

Concerning the role of websites in achieving universities goals, Hanan Junaid (2010) ${ }^{(\mathbf{1 1})}$ aimed in her study to identify the role of websites in achieving the organization communication goals by applying to a sample of public and private universities websites in Egypt and the UAE. The study assured the rise of various detailed contents on private universities sites which included open content, youth-specific content, and the possibility of interaction with professors. There are many uses of universities websites which are able to satisfy students' needs. The results added that private 
universities websites had electronic mail service by (58.3\%) compared to $(41.7 \%)$ for public universities websites which referred to a poor communication between webmasters and visitors.

Deepti (2010) $)^{(\mathbf{1 2})}$ aimed to examine using of various internet tools in public relations in New Zealand, and its impact on skills, ethics and gender balance. The study also aimed to examine the internet development and its impact on the public relations practice. The researcher used the survey methodology, the questionnaire tool applying to a sample of 133 public relations officers, and the interview tool with 10 items. The results of the study showed that there were significant differences in the use of internet tools in public relations work in New Zealand. The public relations officers did not fully understand the nature of the internet and its practice. The study assured the importance of building a bridge between public relations officers, their ages and the job they were doing.

Study of Khayrat Ayad (2009) ${ }^{(\mathbf{1 3})}$ aimed to examine the importance of the internet as a mean of communication for public relations officers applying to a sample of (40) profit and nonprofit organizations in Egypt and the UAE to analyze their websites. The study assured that all organizations considered their websites as an important mean of communication which public relations departments could use to present the institution to the public. Institutions sites do not rely either on the persuasion strategy or the consensus building strategy. Although the use of these two strategies was generally weak, the intensity of this use differed according to the nature of the institution and its state. The study also found that public relations departments were still far from applying the interaction and dialogue principles through the institutions websites. This was limited to the uplink service which allowed the site users to send their opinions, complaints and suggestions via e-mail.

A Study was conducted by Hassan Basfar $(\mathbf{2 0 0 8})^{(14)}$ aimed to identify the relationship between communication and investment in the Saudi stock market. The study examined investors and traders perceptions in the Saudi stock market towards the press, the radio, the television, the personal communication and the internet in shaping their culture, and affecting their dealing and investing decisions. Also, the study examined the role of Capital Market official and non-official 
sources of news and information, heads of companies and businessmen, experts and analysts in the media and the Saudi Press Agency, in shaping investors and traders culture and decisions. The study assured that the personal contact was the first communication tool used by investors, to examine the Saudi money market and buying shares. There was a correlation between the use of the Saudi Stock website on one hand and each of the satisfaction of investors towards communication service on the site, their mental image of the site and their use of it on the other hand. The results showed a correlation between the satisfaction of the study sample regarding using traditional and electronic communication.

To examine the use of public relations in the United Arab Emirates focusing on the characteristics of its officers and its practice, Mohammed kirat $\left(\mathbf{2 0 0 7}^{(\mathbf{1 5})}\right.$ aimed to identify the extent to which communication and information technology used in public relations work and the means used to communicate with external and internal audiences. The study used the survey methodology and the questionnaire applying to public relations officers in private and public institutions in the UAE. Also, the researcher used interviews with public relations officials and officers applying to a sample of (372) items, $(80.2 \%)$ of them belonged to the public sector, and (9.3\%) belonged to the joint sector. The study found that $(90.2 \%)$ of public relations officers wanted to participate in public relations training courses. (42.5\%) of them reported having benefited from training courses prior to taking the job. while $(72.1 \%)$ of the respondents said that they benefited from public relations training after taking the job.

In another study, Sherifa Sulaiman (2006) ${ }^{(\mathbf{1 6})}$ aimed to identify the role of communications and public relations in e-government. The study examined the views and attitudes of e-management in a number of government departments and institutions in Dubai. The researcher chose a sample of 204 companies and institutions. By using the survey and the interview, the study found difference between the website goals of each governmental organization according to its activity's nature and the type of services provided to the public. The study revealed a gap between communicating and marketing real tasks of internet and the actual practice in the public relations activities in 
government organizations. There was a general trend among the registered companies on the municipality website to accept the electronic service, because of the easy access to the site, the development of its services and its ability to keep pace with the modern era. This service helped to activate the electronic channels, however some companies preferred the personal interaction with their employees.

Ahmed Radwan conducted a study (2006) ${ }^{(\mathbf{1 7})}$ aiming to identify the role of the Arab profit organizations websites in building the relationship between these organizations and public various categories by studying the content published on these websites. The study assured that the objectives of public relations ranked first in the these websites objectives, followed by marketing objectives, then promotional objectives and finally sales ones. The study also revealed that these websites were interested in providing information about the organization work, its history in the market, its vision and mission. This helped in creating a good mental image that supported the organization reputation in the market. The websites were also interested in providing information on the administrative characteristics of the organization, its leadership, administrative structure, job opportunities, organization features, as well as topics on the characteristics and types of its products, and information on its financial position. The study also revealed that organizations websites targeted multiple categories of audiences, especially current clients or consumers, media professionals, prospective employees, prospective consumers or clients, and finally the nongovernmental organizations.

To examine the use of internet by public relations departments, Study of Marieke (2005) ${ }^{(\mathbf{1 8})}$ investigated the internet role in public relations activities and in determining strategies that can be used by public relations in order to attract clients, and provide the best services for them. Also, the study aimed to identify the type of activities in which the internet could achieve high level of effectiveness. The researcher chose a German company website "STEF", using the descriptive method and interviews with the mangers of this website. The study found that the internet contributed positively in enhancing the organization efficiency and creating better opportunities to improve the service provided to the customer by receiving his 
inquiries online. The results added that there were many activities in which the internet could be used in the activities of public relation, especially active interaction between customers and public relations officers.

\section{Commentary on literature Review:}

- The results of the studies confirmed the importance of websites in different organizations, which are keen to use the internet in communicating with the public, in order to improve their provided service.

- Previous studies were conducted on different types of organization, which included non-profit organizations such as egovernment in Dubai (Sherifa Sulaiman, 2006), profit organizations (Ahmad Radwan, 2006), and both of them (Khairat Ayad, 2009).The recent study focuses on studying commercial and Islamic banks in the Kingdom of Bahrain, as these banks haven't been studied before.

- Most previous studies used the survey methodology, some of them used the case study method such as the study of (Ahmad Radwan, 2012) which was conducted on Toyota organization crisis, and the study of (Sharifa Sulaiman, 2006), which examined e-government communications in the Emirate of Dubai.

- Previous studies samples were varied according to the methodology of each study. These samples included public relation consultants and officers (Genlio, 2011), internal audiences (kirat, 2007), and external customers (Basfr, 2008). This study population includes Bahraini banks customers.

- Most of these studies used the questionnaire tool and the content analysis tool applying to the organizations websites (Ayad, 2009). Also, the interview tool was used (Deepti, 2010). This study uses the questionnaire tool to collect data.

- This study focuses on banks customers in the Kingdom of Bahrain. While previous studies were concerned with banks in other countries, such as Egypt and the UAE (Ayad 2009), UAE (kirat, 2007), Saudi Arabia (Basfar, 2008), Germany (Schurink Marieke, 2005) and Bangladesh (Genilo, 2011). 


\section{Benefits of literature Review:}

- The review helps to place the research in the context of what has already been done, thus, allowing comparisons to be made. This review helps the researcher in:

- Identifying previous studies fields in order to determine a new study topic.

- Justifying the reason for the research and developing research objectives in studying the role of bank websites in communicating with external customers.

- Working out how to answer the questions and what questions need to be asked regarding the banks' websites activities and their objectives

\section{Statement of Research Problem:}

The success of communicating efforts in an organization depends on the functions of management. This requires a dynamical cooperation and integration between communicating activities and bank efforts in activating the uses of websites in order to achieve its goals.

These websites are a significant communicating phenomenon in organizations which deals with individuals. They are considered an important tool in helping banks to improve human relations on one hand and achieve the banking goals on the other hand.

Despite the importance of websites, its use in Bahrain remains incomplete, but rather absent. This has been determined theoretically not practically.

The effective communication policy between the management of commercial banks and its internal customers leads to gain their employees confidence and satisfaction which affects positively their dealing with external customers, especially regarding competition between banks, and their constant efforts to attract many customers by communicating them through the new ways of communication, such as social networking sites.

In light of previous studies review on websites roles and functions in various organizations and these results, the research 
problem is "Investigating the role of banks' websites in communicating with customers in the Kingdom of Bahrain, and its efficiency in carrying out banks' duties and responsibilities towards customers".

\section{Research Significant}

1- The study is concerned about modern technology and its use in the field of interaction with banks' customers. Most previous studies have not given enough attention to this field, despite using modern technology in banks.

2- Communication in banks has a great importance; it is the main tool in distributing information inside and outside the organization. Interacting through the websites of banks has a significant role in increasing the flow of this information and improving communication process.

3- The websites have become one of the modern communications means in banks around the world, it is applied in customer service departments, and in dealing between the banks' staff and their customers.

4- The role of websites in commercial banks is an important management function, which is difficult to dispense due to the diversity of these banks' activities. This requires effective websites to help banks to identify the attitudes of customers.

\section{Objectives and methodology}

This section includes descriptions of the specific objectives and methods of the study.

\section{Research objectives:}

There have been six primary objectives of this study:

- Identifying the most important means of modern communication used by commercial banks to interact with the customers.

- Identifying the contents that customers prefer to follow on the Bahraini banks websites.

- Examining and analyzing the public relations departments' use of e-mail in communicating with customers. 
- Revealing customers' attitudes towards public relations use of the Internet in Bahraini banks.

- Identifying the importance and advantages of the websites of Bahraini banks from customers' perspective.

- Identifying the role of these websites in interacting with the customers and responding rapidly to their complaints and inquiries.

\section{Research questions:}

Research questions provide the direction to the study and guide the researcher to focus on the core objective of research, they are:

1- What are the modern ways of communication used by Bahraini banks to interact with customers?

2- What are the most important contents that customers preferred to read on the website of Bahraini banks?

3- How far the public relations departments used e-mail to interact with customers?

4- What are the customers' attitudes towards the use of online interaction in public relations departments in Bahraini banks?

5- How do the Bahraini banks' websites use the various attractions elements, in form and content, to interact with the customers?

6- What are the critical points in the Bahraini banks' websites from customers' perspective?

\section{Research hypotheses:}

There are three Hypotheses which the research tries to prove or disprove:

The first hypothesis: There is a statistically significant relationship between the extent to which the public relations departments in Bahraini banks update the banks' websites and customers' attitudes towards the importance of these websites.

The second hypothesis: There is a statistically significant relationship between the weaknesses of the Bahraini banks' websites and customers' attitudes towards the importance of these websites. 
The third hypothesis: There is a statistically significant relationship between the extent to which Bahraini banks' managements update the banks websites and customers' attitudes towards the importance of these websites.

\section{Research type:}

This study belongs to Descriptive Researches, which aims to describe characteristics of a population or phenomenon being studied. It does not answer questions about how/when/why the characteristics occurred. Rather it addresses the "what" question (what are the characteristics of the population or situation being studied?) ${ }^{(19)}$.The characteristics used to describe the situation or populations are usually some kind of categorical scheme also known as descriptive categories.

The study has sought to identify the role of websites of Bahraini Islamic and commercial banks. It has examined the use of these websites by the Bahraini customers, and their important contents from customers' perspective.

\section{Research method:}

The study has used the survey method, which is used to collect data from a pre-defined group of respondents to gain information and insights on various topics of interest. Surveys have a variety of purposes and can be carried out in many ways depending on the methodology chosen and the objectives to be achieved ${ }^{\mathbf{( 2 0 )}}$, the current study has used this method in order to identify the attitudes of customers towards Bahraini banks in light of using modern communication technology.

\section{Research population:}

Study population refers to the sample of participants that will be recruited to the study sharing the same characteristics ${ }^{(21)}$.

Sampling is the process whereby a researcher chooses the study sample. Because sampling isn't as straightforward as it initially seems, there is a set process to help researchers choose a good sample to collect data which enables the researcher to achieve the research objectives ${ }^{(22)}$. 
The current study population is customers who deal with Bahrain's commercial and Islamic banks.

The study has depended on a simple random sample because banks refused to provide customer lists to keep them confidential. The study required two main items in selecting its sample:

- The customer has an account in the bank for more than one year.

- The customer deals with the bank main branch.

A total of 300 questionnaires were distributed to gather information from customers in Bahrain's commercial and Islamic banks, after excluding questionnaires that did not include answers to all questions, the study sample included 241 customers (137 of commercial banks and 104 of Islamic banks). The commercial banks include (National Bank of Bahrain, Ahli United Bank, Gulf commercial Bank), while the Islamic banks include (Bahrain Islamic Bank Al Baraka Islamic Bank, ABC Islamic Bank). The researcher has selected these banks because of being the major banks in the Kingdom of Bahrain according to the Central Bank of Bahrain statistics.

\section{Research tool:}

To achieve the objectives of the study, the researcher designed a questionnaire, a research instrument consisting of a series of questions for the purpose of gathering information from respondents and analyzing it ${ }^{(\mathbf{2 3})}$, in order to provide facts and opinions related to the subject of study and its objectives ${ }^{(24)}$.

\section{The pre-test:}

A pre-test is where a questionnaire has been tested on a (statistically) small sample of respondents (25 customers, about $10 \%$ of the sample size) before a full-scale study, in order to identify any problems, such as the respondent misunderstanding, unclear wording or the questionnaire taking too long to administer. A pre-test has been also used to refer to an initial measurement (such as brand or advertising awareness) before an experimental treatment is administered and subsequent measurements are taken. It helped the 
researcher to determine how respondents can cooperate with the researcher during the application of the questionnaire, and to identify the period of time to answer the questionnaire.

\section{Reliability and validity}

Reliability and validity are two concepts that are important for defining and measuring bias and distortion.

\section{A. Questionnaire reliability:}

Reliability is the degree of consistency of a measure. A test will be reliable when it gives the same repeated result under the same conditions. The questionnaire of this study has been modified by being submitted to a group of experts in the field of media and public relations $^{(*)}$, then it has been modified in accordance with their observations.

\section{B. Questionnaire validity:}

Validity of a questionnaire is the degree to which it measures what it is supposed to measure. Validity is also dependent on the measurement measuring what it has been designed to measure, and not something else instead.

The questionnaire has been reapplied after two weeks of its first application. The researcher has used the Pearson correlation coefficient to measure the statistical relationship, or association, between two continuous variables the stability coefficient reached to (0.86), which indicates that there is no significant difference in

* Arbitrators:

- Prof. Allam Hamdan, Professor of Statistics, dean of College of Business and Finance Ahlia University.

- Prof. Mohammed Mowaad, Professor of Professor of Mass Communication, Ain Shams University.

- Dr. Kazem Aziz Mounes, Associate Professor of Mass Communication - Al Ahlia University - Kingdom of Bahrain. 
respondent's answers, so the questionnaire has a high degree of validity.

\section{Statistical methods used:}

The researcher has used the statistical analysis of data using the Statistical Package for Social Sciences (SPSS). Statistical analysis is the use of statistical data including varying variables, entities, and events to determine probabilistic or statistical relationships in quantitative manner.

\section{The following statistical tests were used:}

1- Simple sequence repeats and percentages.

2- Arithmetic averages and standard deviations.

3- T-Test for independent groups to study the differences between the arithmetical averages of two groups of respondents according to the type of bank (commercial or Islamic).

4- Z-Test to study difference significance between the two percentages of two groups of respondents according to the type of bank (commercial banks - Islamic banks) .

5- Pearson correlation coefficient to study the intensity and direction of the correlation between two variables of the study variables.

6- The percentage weight calculated from the following equation:

\section{Percentage weight $=$ the arithmetic mean $\times 100 \div$ the maximum degree of statement.}

\section{Research terms:}

- Attitudes: The position towards which someone or something moves or faces, supporting or opposing an idea, preferring a concept or not, or building a positive or negative view towards a subject. The "Likert scale" is used to measure trends. It is a fivepoint scale which is used to allow individuals to express how much they agree or disagree with a particular statement. It includes five paragraphs: Strongly agree / agree / don't know / disagree / strongly disagree 
- Customers: They are individuals who deal with Bahraini commercial and Islamic banks who have personal accounts in these banks.

- Websites: Website is a collection of related network web resources, such as web pages, and multimedia contents, which are typically identified with a common domain name, and published on at least one web server. Here, the researcher means the websites of banks.

- Interactive Communication: it is an exchange of ideas where both participants, (human, machine or art form), are active and can have an effect on one another. The researcher has determined these both sides in: customers on one hand, and websites of Islamic and commercial Bahraini banks on the other hand.

- Banks: in this study, the Bank means a commercial or an Islamic financial institution that accepts deposits from the public and creates credit in the Kingdom of Bahrain, and licensed by the Central Bank of Bahrain to carry out various banking activities, such as: investing or borrowing money, changing it to foreign money, netting and settlement of payments, Money creation/destruction, credit quality improvement and credit intermediation ${ }^{(25)}$.

- Islamic Bank: it is a financing activity that complies with sharia (Islamic law) and its practical application through the development of Islamic economics and rules. This bank tries to maintain social solidarity. Its activities are in line with Islamic principles, it prohibits all forms of interest, it collects "zakat" from customers' accounts according to some sources Also, it prohibits investing in businesses involved in activities that are forbidden ${ }^{(26)}$.

Islamic banks have been able to introduce a new concept of banking. Many Bahraini banks have sought to create Islamic departments to meet the growing demand of their Muslim clients for Sharia-compliant banking services.

The first Islamic bank opened in Bahrain is the Islamic Bank of Bahrain in 1979, then, Islamic banks were established in 
various GCC countries, such as $\mathrm{Al}$ Baraka Islamic Bank, $\mathrm{ABC}$ Islamic Bank, Ithmaar Bank, Kuwait Finance Bank ${ }^{(27) .}$

- Commercial Bank: it is a type of financial institution that accepts deposits, offers checking account services, makes various loans, and offers basic financial products. Its primary function is to collect money from its holders in the form of current deposits and loans at a predefined interest rate, and re-lending them to those who demand with a greater rate.

The Bank wins the difference between the two rates and provides the banking services related to lending and loaning operations ${ }^{(28)}$.

The first commercial bank in Bahrain was established on January 1, 1957, followed by Ahli United Bank, Khaleeji Commercial Bank, Arab Bank and Bank Muscat ${ }^{(29)}$.

\section{Data analysis and interpretations}

In the research work, data collection, tabulation, analysis and interpretation is very important. This section presents answers to questions, testing of hypothesis and interpretation of the results.

- Descriptive statistics: Simple frequencies and percentages.

- Mean and standard deviation.

- Pearson relationship coefficient to study the intensity and direction of the relationship between two variables of the study variables. The relationship is weak if the value of the coefficient is $(<0.30)$, and moderate if the value is between $(0.30-0.70)$, and strong if the value is $(>0.70)$.

- T-Test for independent groups to study the differences between the mean of two groups of respondents according to the type of the institution.

- Z-test to study difference significance between the two percentages of two groups of respondents. 
Table (1)

The communication means used by Bahraini Banks to contact customers

\begin{tabular}{|c|c|c|c|c|c|c|c|c|}
\hline \multirow[t]{2}{*}{$\begin{array}{c}\text { Communication } \\
\text { means }\end{array}$} & \multicolumn{2}{|c|}{$\begin{array}{c}\text { Commercial } \\
\text { Banks }\end{array}$} & \multicolumn{2}{|c|}{$\begin{array}{c}\text { Islamic } \\
\text { Banks }\end{array}$} & \multicolumn{2}{|c|}{ Total } & \multirow[t]{2}{*}{$\begin{array}{l}\text { Z- } \\
\text { Test }\end{array}$} & \multirow[t]{2}{*}{$\begin{array}{l}\text { significance } \\
\text { level }\end{array}$} \\
\hline & $\mathrm{F}$ & $\%$ & $\mathrm{~F}$ & $\%$ & $\mathrm{~F}$ & $\%$ & & \\
\hline bank website & 77 & 56.20 & 54 & 51.92 & 131 & 54.36 & .66 & Non significant \\
\hline E-mail & 65 & 47.45 & 101 & 97.12 & 166 & 68.88 & 8.25 & Significant \\
\hline SMS & 55 & 40.15 & 89 & 85.58 & 144 & 59.75 & 7.01 & Significant \\
\hline Social Media & 38 & 27.74 & 65 & 62.50 & 103 & 42.74 & 5.40 & Significant \\
\hline Mobil Phone & 13 & 9.49 & 22 & 21.15 & 35 & 14.52 & 2.55 & Significant \\
\hline Total & & & & & & 41 & & \\
\hline
\end{tabular}

The table shows that:

- The e-mail ranked first in modern communication means used by the bank's management to communicate with the customers $(68.88 \%)$, followed by short messages $(59.75 \%)$, the bank's website ranked third $(54.36 \%)$, then the social networking sites $(42.74 \%)$, and the latter at the low end $(14.52 \%)$.

- The results of the study show significant statistical differences between commercial and Islamic banks in using the modern communication means to communicate with their customers. Islamic banks are superior to commercial ones in using e-mail, SMS, social networking sites by $(97.12 \%),(85.58 \%),(62.50 \%)$ versus $(47.45 \%),(40.15 \%)$, and $(27.74 \%)$. This is a relative significant difference; the Z-test value is greater than 2.58 , which indicates that there is a significant relationship between the two variables with a (99\%) confidence level.

- Also, Islamic banks are superior to commercial ones in using mobile phone by (21.15) vs. (9.49\%). This is a relative significant difference; the Z-test value is greater than (1.96), which indicates that there is a relationship between the two variables with a (99\%) confidence level.

Table (2)

The extent to which Bahraini banks update their website

\begin{tabular}{|c|c|c|c|c|c|c|c|c|c|c|c|c|c|}
\hline \multirow{2}{*}{$\begin{array}{l}\text { Updating } \\
\text { the } \\
\text { website }\end{array}$} & \multicolumn{4}{|c|}{ Commercial Banks } & \multicolumn{4}{|c|}{ Islamic Banks } & \multicolumn{2}{|c|}{ Total } & \multirow{2}{*}{$\begin{array}{l}\text { T. } \\
\text { Test } \\
\end{array}$} & \multirow{2}{*}{$\begin{array}{l}\text { Freedom } \\
\text { degree }\end{array}$} & \multirow{2}{*}{$\begin{array}{c}\text { significance } \\
\text { level }\end{array}$} \\
\hline & $\bar{F}$ & $\%$ & Arithmetic & $\begin{array}{l}\text { Standard } \\
\end{array}$ & F & $\%$ & Arithmetic & Standard & F & $\%$ & & & \\
\hline
\end{tabular}




\begin{tabular}{|c|c|c|c|c|c|c|c|c|c|c|c|c|c|}
\hline & & & Mean & deviation & & & Mean & deviation & & & & & \\
\hline Always & 27 & 19.71 & \multirow{4}{*}{1.408} & \multirow{4}{*}{.575} & 15 & 14.42 & \multirow{4}{*}{1.240} & \multirow{4}{*}{.451} & 42 & 17.43 & \multirow{4}{*}{2.462} & \multirow{4}{*}{239} & \multirow{4}{*}{.015} \\
\hline Often & 48 & 35.04 & & & 35 & 33.65 & & & 83 & 34.44 & & & \\
\hline Rarely & 32 & 23.36 & & & 28 & 26.92 & & & 60 & 24.90 & & & \\
\hline Never & 30 & 21.90 & & & 26 & 25.00 & & & 56 & 24.24 & & & \\
\hline Total & 137 & 100 & & & 104 & & & & 241 & & & & \\
\hline
\end{tabular}

The previous table indicates that:

- The customers see that the Bank's management updated the bank website sometimes by $(34.44 \%)$, then rarely by $(24.90 \%)$ and always by $(17.43 \%)$, while $(23.42 \%)$ says that the bank's management never updated its website.

- There is a statistically significant difference between commercial and Islamic banks in the extent of updating their websites in favor of commercial banks with an average of (1.408) versus (1.240) for Islamic banks. This is a statistically significant difference; the $\mathrm{T}$ - test value is (2.462), which is a statistically significant value at a significance level of (.015), which is less than (.05).

\section{Table (3)}

The Bahraini banks' websites preferred content

\begin{tabular}{|c|c|c|c|c|c|c|c|c|}
\hline Contents & Banks & $\mathrm{N}$ & $\begin{array}{l}\text { Arithmetic } \\
\text { Mean }\end{array}$ & $\begin{array}{l}\text { Standard } \\
\text { deviation }\end{array}$ & $\begin{array}{l}\text { T- } \\
\text { Test }\end{array}$ & $\begin{array}{l}\text { Freedom } \\
\text { degree }\end{array}$ & $\begin{array}{l}\text { significance } \\
\text { level }\end{array}$ & $\begin{array}{l}\text { Percentage } \\
\text { weight }\end{array}$ \\
\hline \multirow{2}{*}{$\begin{array}{l}\text { information about bank } \\
\text { services }\end{array}$} & Commercial & 137 & 1.9124 & .79033 & \multirow[t]{2}{*}{2.140} & \multirow{2}{*}{239} & \multirow[t]{2}{*}{.033} & \multirow[t]{2}{*}{60.70} \\
\hline & Islamic & 104 & 1.7019 & .70889 & & & & \\
\hline \multirow{2}{*}{$\begin{array}{l}\text { Information about the bank } \\
\text { role in its society }\end{array}$} & Commercial & 137 & 1.7445 & .72790 & \multirow[t]{2}{*}{1.977} & \multirow{2}{*}{239} & \multirow[t]{2}{*}{.049 } & \multirow[t]{2}{*}{56.26} \\
\hline & Islamic & 104 & 1.5673 & .63497 & & & & \\
\hline \multirow{2}{*}{$\begin{array}{l}\text { Banks' phone numbers and } \\
\text { e-mail }\end{array}$} & Commercial & 137 & 1.5912 & .64801 & \multirow[t]{2}{*}{1.958} & \multirow{2}{*}{239} & \multirow[t]{2}{*}{.051} & \multirow[t]{2}{*}{50.73} \\
\hline & Islamic & 104 & 1.4327 & .58732 & & & & \\
\hline \multirow[t]{2}{*}{ videos of bank services } & Commercial & 137 & 1.6131 & .71997 & \multirow[t]{2}{*}{1.747} & \multirow{2}{*}{239} & \multirow[t]{2}{*}{.082} & \multirow[t]{2}{*}{50.56} \\
\hline & Islamic & 104 & 1.4615 & .58993 & & & & \\
\hline \multirow{2}{*}{$\begin{array}{l}\text { Bank's annual and } \\
\text { periodical reports }\end{array}$} & Commercial & 137 & 1.7518 & .71518 & \multirow[t]{2}{*}{.891} & \multirow{2}{*}{239} & \multirow[t]{2}{*}{.374} & \multirow[t]{2}{*}{57.23} \\
\hline & Islamic & 104 & 1.6731 & .63003 & & & & \\
\hline \multirow{2}{*}{ Banks leading figures } & Commercial & 137 & 2.2847 & .71691 & \multirow[t]{2}{*}{2.460} & \multirow{2}{*}{239} & \multirow[t]{2}{*}{.015} & \multirow[t]{2}{*}{72.73} \\
\hline & Islamic & 104 & 2.0481 & .76805 & & & & \\
\hline \multirow[t]{2}{*}{ Banks' Publications review } & Commercial & 137 & 1.8686 & .69470 & \multirow[t]{2}{*}{1.726} & \multirow{2}{*}{239} & \multirow[t]{2}{*}{.086} & 60.00 \\
\hline & Islamic & 104 & 1.7115 & .70605 & & & & \\
\hline Bank's activities & Commercial & 137 & 2.4380 & .69517 & .057 & 232 & .954 & 81.16 \\
\hline & Islamic & 104 & 2.4327 & .72090 & & 239 & & \\
\hline Saving and investments & Commercial & 137 & 2.0438 & .74625 & 2.618 & & 000 & 64.56 \\
\hline $\begin{array}{l}\text { opportunities offered by } \\
\text { the bank }\end{array}$ & Islamic & 104 & 1.7981 & .68804 & & 239 & .009 & \\
\hline Conducting bank & Commercial & 137 & 2.0219 & .78090 & 1.093 & 230 & .276 & 65.83 \\
\hline transactions via the website & Islamic & 104 & 1.9135 & .73881 & & 239 & & \\
\hline
\end{tabular}




\section{The previous table shows that:}

- The contents preferred by respondents to read on the websites of Bahraini banks are (in sequence): the activities provided by the bank $(81.16 \%)$, the bank leading figures $(72.73 \%)$, how to conduct banking transactions through the bank's website $(65.83 \%)$, the investment and savings opportunities provided by the bank (64.56\%), information about the banks' services $(60.70 \%)$, the bank annual and periodical reports $(57.23 \%)$, information about the bank' role in society (56.26\%), the bank phone numbers and e-mail (50.73\%), and videos about bank's services $(50.56 \%)$.

- there are significant statistical differences between commercial and Islamic banks in the extent of updating their websites in favor of commercial banks regarding information about the bank's services, information about the bank's role in society, the bank's leading figures, and opportunities of investment and savings offered by the bank with an arithmetic average of (1.9124), (1.7445), (2.2847), (2.0438) vs. (1.7019), (1.5673), (2.0481), (2.0438) for Islamic banks respectively. The difference is statistically significant; the values of the significance level are less than (.05).

Table (4)

\section{Aspects of e-mail use by banks' management to communicate} customers

\begin{tabular}{|c|c|c|c|c|c|c|c|c|}
\hline Aspects of E-mail uses & Banks & $\mathrm{N}$ & $\begin{array}{c}\text { Arithmetic } \\
\text { Mean }\end{array}$ & $\begin{array}{l}\text { Standard } \\
\text { deviation }\end{array}$ & $\begin{array}{l}\text { T- } \\
\text { Test }\end{array}$ & $\begin{array}{l}\text { Freedom } \\
\text { degree }\end{array}$ & $\begin{array}{l}\text { significance } \\
\text { level }\end{array}$ & $\begin{array}{c}\text { Percentage } \\
\text { weight }\end{array}$ \\
\hline \multirow{2}{*}{$\begin{array}{l}\text { Communicating customers and providing them } \\
\text { with bank's important information and news }\end{array}$} & Commercial & 137 & 2.6788 & 1.13068 & \multirow{2}{*}{-961} & \multirow{2}{*}{239} & \multirow{2}{*}{.338} & \multirow{2}{*}{91.26} \\
\hline & Islamic & 104 & 2.8173 & 1.07725 & & & & \\
\hline \multirow{2}{*}{$\begin{array}{l}\text { Receiving messages, reactions, suggestions, } \\
\text { inquires and rapidly responding to them to } \\
\text { facilitate communication between the bank and } \\
\text { its customers }\end{array}$} & Commercial & 137 & 2.4599 & 1.07111 & \multirow[b]{2}{*}{-.953} & \multirow[b]{2}{*}{239} & \multirow[b]{2}{*}{.342} & \multirow[b]{2}{*}{83.93} \\
\hline & Islamic & 104 & 2.5962 & 1.13650 & & & & \\
\hline \multirow{2}{*}{$\begin{array}{l}\text { Messages exchange between (PR) department } \\
\text { and the other departments in order to solve } \\
\text { customers' problems }\end{array}$} & Commercial & 137 & 1.4088 & .49341 & \multirow[b]{2}{*}{-.372} & \multirow[b]{2}{*}{239} & \multirow[b]{2}{*}{.711} & \multirow[b]{2}{*}{47.30} \\
\hline & Islamic & 104 & 1.4327 & .49785 & & & & \\
\hline \multirow{2}{*}{$\begin{array}{l}\text { Identifying customers inquires and informing the } \\
\text { head office }\end{array}$} & Commercial & 137 & 1.7153 & .68545 & \multirow{2}{*}{-.621} & \multirow{2}{*}{239} & \multirow{2}{*}{.535} & \multirow{2}{*}{57.93} \\
\hline & Islamic & 104 & 1.7692 & .64207 & & & & \\
\hline \multirow{2}{*}{ Explaining bank's policy to customers } & Commercial & 137 & 2.1898 & .95896 & \multirow{2}{*}{1.907} & \multirow{2}{*}{239} & \multirow{2}{*}{.058} & \multirow{2}{*}{69.56} \\
\hline & Islamic & 104 & 1.9519 & .95916 & & & & \\
\hline Responding to harmful rumors about the bank & Commercial & 137 & 2.1460 & .65910 & .354 & 239 & .724 & 71.06 \\
\hline
\end{tabular}




\begin{tabular}{|c|c|c|c|c|c|c|c|c|}
\hline & Islamic & 104 & 2.1154 & .67274 & & & & \\
\hline \multirow{2}{*}{$\begin{array}{l}\text { Getting customers to participate in some events } \\
\text { held by the bank }\end{array}$} & Commercial & 137 & 1.4088 & .57592 & \multirow{2}{*}{2.462} & \multirow{2}{*}{239} & \multirow{2}{*}{.015} & \multirow{2}{*}{44.53} \\
\hline & Islamic & 104 & 1.2404 & .45143 & & & & \\
\hline \multirow{2}{*}{ Marketing the services provided by the bank } & Commercial & 137 & 1.7518 & .49677 & \multirow{2}{*}{.028} & \multirow{2}{*}{239} & \multirow{2}{*}{.978} & \multirow{2}{*}{58.36} \\
\hline & Islamic & 104 & 1.7500 & .51671 & & & & \\
\hline \multirow{2}{*}{$\begin{array}{l}\text { Receiving customers evaluation of banks } \\
\text { programs and activities }\end{array}$} & Commercial & 137 & 2.1387 & .65510 & \multirow{2}{*}{-.787} & \multirow{2}{*}{239} & \multirow{2}{*}{.432} & \multirow{2}{*}{72.20} \\
\hline & Islamic & 104 & 2.2019 & .56396 & & & & \\
\hline \multirow{2}{*}{$\begin{array}{c}\text { Informing the customers with latest devices and } \\
\text { techniques used by the bank and its obtained } \\
\text { awards }\end{array}$} & Commercial & 137 & 1.7226 & .48096 & \multirow[b]{2}{*}{.023} & \multirow[b]{2}{*}{239} & \multirow[b]{2}{*}{.982} & \multirow[b]{2}{*}{57.40} \\
\hline & Islamic & 104 & 1.7212 & .51117 & & & & \\
\hline
\end{tabular}

\section{The previous table indicates that:}

- Bank's use of e-mail in communicating customers include connecting with them and providing them with the most important information and news about the bank (91.26\%), receiving messages, feedback, suggestions and inquiries quickly to facilitate communication between the bank and its customers $(83.93 \%)$, receiving customers' evaluation of the bank's programs and activities ( $72.20 \%$ ), responding to rumors about the bank $(71.06 \%)$, explaining the bank's policy to the customers $(69.56 \%)$, marketing the bank's services (58.36\%), identifying customer requirements and informing the bank's management (57.93\%), informing customers of the latest devices and techniques used by the bank and its obtained awards (57.40\%), exchanging messages between the public relations department and other departments to solve customer problems (47.30\%), and getting customers to participate in some events held by the bank $(44.53 \%)$.

- There are significant statistical differences between commercial and Islamic banks according to aspects of e-mail use by bank's management to communicate with customers in favor of commercial banks in getting customers to participate in some events held by the bank with an average of (1.4088) against (1.2404) for Islamic banks. This difference is statistically significant; the significance level values are less than (.05). 
Table (5)

Customers' attitudes towards the internet use in Bahraini banks

\begin{tabular}{|c|c|c|c|c|c|c|c|c|}
\hline Attitudes & Banks & $\mathrm{N}$ & $\begin{array}{l}\text { Arithmetic } \\
\text { Mean }\end{array}$ & $\begin{array}{l}\text { Standard } \\
\text { deviation }\end{array}$ & T-Test & $\begin{array}{c}\text { Freedom } \\
\text { level }\end{array}$ & significance level & $\begin{array}{c}\text { Percenttage } \\
\text { weight }\end{array}$ \\
\hline \multirow{2}{*}{$\begin{array}{l}\text { The internet supports } \\
\text { communication } \\
\text { process of public } \\
\text { relations }\end{array}$} & Commercial & 137 & 1.8102 & .72287 & \multirow[b]{2}{*}{.549} & \multirow[b]{2}{*}{239} & \multirow[b]{2}{*}{.584} & \multirow[b]{2}{*}{59.26} \\
\hline & Islamic & 104 & 1.7596 & .68966 & & & & \\
\hline \multirow{2}{*}{$\begin{array}{l}\text { Internet reduces time } \\
\text { and fffort to get the } \\
\text { work of public } \\
\text { relations done }\end{array}$} & Commercial & 137 & 2.0438 & .74625 & \multirow[b]{2}{*}{2.618} & \multirow[b]{2}{*}{239} & \multirow[b]{2}{*}{.009} & \multirow[b]{2}{*}{64.56} \\
\hline & Islamic & 104 & 1.7981 & .68804 & & & & \\
\hline \multirow{2}{*}{$\begin{array}{l}\text { The internet affects } \\
\text { personal and human } \\
\text { interactions within } \\
\text { the bank negatively }\end{array}$} & Commercial & 137 & 2.0219 & .78090 & \multirow[b]{2}{*}{1.093} & \multirow[b]{2}{*}{239} & \multirow[b]{2}{*}{.276} & \multirow[b]{2}{*}{65.83} \\
\hline & Islamic & 104 & 1.9135 & .73881 & & & & \\
\hline \multirow{2}{*}{$\begin{array}{l}\text { The bank's } \\
\text { management is } \\
\text { encouraged to hold } \\
\text { training courses for } \\
\text { employees to use the } \\
\text { internet in dealing } \\
\text { with customers }\end{array}$} & Commercial & 137 & 1.9562 & .68458 & \multirow[b]{2}{*}{2.245} & \multirow[b]{2}{*}{239} & \multirow[b]{2}{*}{.026} & \multirow[b]{2}{*}{62.23} \\
\hline & Islamic & 104 & 1.7500 & .73405 & & & & \\
\hline \multirow{2}{*}{$\begin{array}{l}\text { The E-mail services } \\
\text { facilitates } \\
\text { communicating } \\
\text { between the bank and } \\
\text { its customers }\end{array}$} & Commercial & 137 & 2.2885 & .74616 & \multirow[b]{2}{*}{2.975} & \multirow[b]{2}{*}{239} & \multirow[b]{2}{*}{.003} & \multirow[b]{2}{*}{81.30} \\
\hline & Islamic & 104 & 2.5547 & . 64077 & & & & \\
\hline \multirow{2}{*}{$\begin{array}{l}\text { The public relations } \\
\text { department gets } \\
\text { benefits from File } \\
\text { Transfer Protocol } \\
\text { (FTP) in sending } \\
\text { cusstomers circulars }\end{array}$} & Commercial & 137 & 2.2920 & .71907 & \multirow[b]{2}{*}{1.419} & \multirow[b]{2}{*}{239} & \multirow[b]{2}{*}{. 157} & \multirow[b]{2}{*}{74.40} \\
\hline & Islamic & 104 & 2.1538 & .78542 & & & & \\
\hline
\end{tabular}

The previous data shows that:

- Respondents' attitudes towards the internet use in Bahraini banks are (in order): the e-mail service facilitate communication between the bank and its customers $(81.30 \%)$, the public relations department benefits from File Transfer Protocol (FTP) in sending customers circulars (76.73\%), the Bank's management makes use of the internet in preparing and holding seminars, lectures and attending the bank's general assembly (74.40\%), the internet has an effect in reducing the time and effort required to complete the work of various departments in the bank (62.23\%), the bank's management encourages holding training courses for employees to promote using of internet in dealing with customers (69.56\%), The 
internet supports communication process of public relations (59.26\%), public relations department benefits from the internet in preparing and holding seminars, lectures and attending public assemblies (59.16\%).

- There are significant differences between the banks under study according to the following statements: the internet has an effect in reducing the time and effort required to do the job of public relations, and the internet has a negative effect on personal interactions within the bank. These significant differences are in favor of commercial banks with an average of (2.0438), and (1.9562) vs. (1.7981), and (1.7500) for Islamic banks.

- Also, there are significant differences between the two banks under study in favor of Islamic banks according to the following statements: the e-mail service facilitates communication between the bank and its customers, and the public relations department benefits from the internet in preparing, holding seminars, lectures and attending bank's general assembly with an average of (2.5547), (1.8759) vs. (2.2885), (2.2885) for commercial banks, this difference is significant statistically, the values of the significance level are less than the value of (.05).

\section{Table (6)}

Customers' attitudes towards the website importance in Bahraini banks

\begin{tabular}{|c|c|c|c|c|c|c|c|c|}
\hline attitudes & Banks & $\mathrm{N}$ & $\begin{array}{l}\text { Arithmetic } \\
\text { Mean }\end{array}$ & $\begin{array}{l}\text { Standard } \\
\text { deviation }\end{array}$ & $\begin{array}{l}\text { T- } \\
\text { Test }\end{array}$ & $\begin{array}{c}\begin{array}{c}\text { Freedom } \\
\text { degree }\end{array} \\
\text { deg }\end{array}$ & $\begin{array}{l}\text { significance } \\
\text { level }\end{array}$ & $\begin{array}{l}\text { Percentage } \\
\text { weight }\end{array}$ \\
\hline \multirow{2}{*}{$\begin{array}{l}\text { An attractive and } \\
\text { important way to attract } \\
\text { customers }\end{array}$} & Commercial & 137 & 1.9708 & .82196 & \multirow[b]{2}{*}{.093 } & \multirow[b]{2}{*}{239} & \multirow[b]{2}{*}{.926} & \multirow[t]{2}{*}{65.53} \\
\hline & Islamic & 104 & 1.9615 & .68156 & & & & \\
\hline \multirow{2}{*}{$\begin{array}{c}\text { A way to develop } \\
\text { electronic transaction } \\
\text { between the bank and its } \\
\text { customers }\end{array}$} & Commercial & 137 & 1.8248 & .70604 & \multirow[b]{2}{*}{-.862} & \multirow[b]{2}{*}{239} & \multirow[b]{2}{*}{.390} & \multirow[t]{2}{*}{61.93} \\
\hline & Islamic & 104 & 1.9038 & .70393 & & & & \\
\hline \multirow{2}{*}{$\begin{array}{c}\text { A way to identify the } \\
\text { bank's provided services }\end{array}$} & Commercial & 137 & 2.4599 & .67535 & \multirow{2}{*}{.403 } & \multirow{2}{*}{239} & \multirow{2}{*}{.687 } & \multirow[t]{2}{*}{81.46} \\
\hline & Islamic & 104 & 2.4231 & .73329 & & & & \\
\hline \multirow{2}{*}{$\begin{array}{l}\text { A means of expanding } \\
\text { bank's services }\end{array}$} & Commercial & 137 & 1.7445 & .68631 & \multirow{2}{*}{-.898} & \multirow{2}{*}{239} & \multirow{2}{*}{.370} & \multirow[t]{2}{*}{59.33} \\
\hline & Islamic & 104 & 1.8269 & .72997 & & & & \\
\hline \multirow{2}{*}{$\begin{array}{l}\text { Easy access to local and } \\
\text { international markets }\end{array}$} & Commercial & 137 & 2.2628 & .75020 & \multirow{2}{*}{1.009} & \multirow{2}{*}{239} & \multirow{2}{*}{.314} & \multirow[t]{2}{*}{73.96} \\
\hline & Islamic & 104 & 2.1635 & .76464 & & & & \\
\hline \multirow{2}{*}{$\begin{array}{l}\text { A way to collect } \\
\text { information on } \\
\text { competing banks through } \\
\text { the banks' websites }\end{array}$} & Commercial & 137 & 2.3358 & .69955 & \multirow[b]{2}{*}{.811} & \multirow[b]{2}{*}{239} & \multirow[b]{2}{*}{.418 } & \multirow[t]{2}{*}{76.73} \\
\hline & Islamic & 104 & 2.2596 & .75034 & & & & \\
\hline
\end{tabular}




\section{The previous data refers to:}

- There are various attitudes of respondents towards the importance of Bahraini banks' websites, they are: these websites are a means of identifying the services provided by the bank $(81.46 \%)$, a way to gather information on competing banks (76.73\%), an easy access to local and international markets (73.96\%), an attractive and important way to attract customers (65.53\%), a means of developing electronic transactions between the bank and its customers (61.93\%), and a means of expanding banking services (59.33\%).

- There are no statistically significant differences between commercial and Islamic banks according to customers attitudes towards the importance of the Bahraini banks' website, the values of the significance level are greater than (.005).

\section{Table (7)}

\section{Customers' attitudes towards the use of Bahraini banks' websites}

\begin{tabular}{|c|c|c|c|c|c|c|c|c|}
\hline $\begin{array}{l}\text { The website } \\
\text { importance }\end{array}$ & Banks & $\mathrm{N}$ & $\begin{array}{l}\text { Arithmetic } \\
\text { Mean }\end{array}$ & $\begin{array}{l}\text { Standard } \\
\text { deviation }\end{array}$ & $\begin{array}{c}\text { T- } \\
\text { Test }\end{array}$ & $\begin{array}{c}\text { Freedom } \\
\text { degree }\end{array}$ & $\begin{array}{c}\text { Significance } \\
\text { level }\end{array}$ & $\begin{array}{c}\text { Percentage } \\
\text { weight }\end{array}$ \\
\hline \multirow{2}{*}{$\begin{array}{l}\text { Providing banking } \\
\text { services to } \\
\text { customers }\end{array}$} & Commercial & 137 & 1.2879 & .45624 & \multirow[b]{2}{*}{$\begin{array}{c}- \\
3.165\end{array}$} & \multirow[b]{2}{*}{239} & \multirow[b]{2}{*}{.002} & \multirow[b]{2}{*}{48.93} \\
\hline & Islamic & 104 & 1.5371 & .57490 & & & & \\
\hline \multirow{2}{*}{$\begin{array}{l}\text { Marketing the bank's } \\
\text { products and } \\
\text { services }\end{array}$} & Commercial & 137 & 1.2879 & .51932 & \multirow{2}{*}{$\begin{array}{c}- \\
3.385\end{array}$} & \multirow{2}{*}{239} & \multirow{2}{*}{.001} & \multirow{2}{*}{49.76} \\
\hline & Islamic & 104 & 1.5714 & .60104 & & & & \\
\hline \multirow{2}{*}{$\begin{array}{c}\text { Introducing services } \\
\text { provided by other } \\
\text { banks }\end{array}$} & Commercial & 137 & 1.4697 & .66146 & \multirow{2}{*}{$\begin{array}{c}- \\
1.770\end{array}$} & \multirow{2}{*}{239} & \multirow{2}{*}{.078} & \multirow{2}{*}{52.96} \\
\hline & Islamic & 104 & 1.6343 & .63696 & & & & \\
\hline \multirow{2}{*}{$\begin{array}{l}\text { Establishing the } \\
\text { brand and trade } \\
\text { name of the bank } \\
\text { among customers }\end{array}$} & Commercial & 137 & 1.3636 & .57208 & \multirow[b]{2}{*}{2.404} & \multirow[b]{2}{*}{239} & \multirow[b]{2}{*}{.017} & \multirow[b]{2}{*}{51.03} \\
\hline & Islamic & 104 & 1.5943 & .69561 & & & & \\
\hline \multirow{2}{*}{$\begin{array}{c}\text { Responding to } \\
\text { public inquiries and } \\
\text { complaints }\end{array}$} & Commercial & 137 & 1.3030 & .55386 & \multirow[b]{2}{*}{-.777} & \multirow[b]{2}{*}{239} & \multirow[b]{2}{*}{.438} & \multirow[b]{2}{*}{44.93} \\
\hline & Islamic & 104 & 1.3657 & .56014 & & & & \\
\hline \multirow{2}{*}{$\begin{array}{c}\text { Realizing the } \\
\text { potential of } \\
\text { electronic purchase }\end{array}$} & Commercial & 137 & 1.3182 & .58597 & \multirow[b]{2}{*}{$\begin{array}{c}- \\
1.956\end{array}$} & \multirow[b]{2}{*}{239} & \multirow[b]{2}{*}{.052} & \multirow[b]{2}{*}{47.96} \\
\hline & Islamic & 104 & 1.4857 & .59555 & & & & \\
\hline \multirow{2}{*}{$\begin{array}{l}\text { Realizing the } \\
\text { potential of } \\
\text { canceling any } \\
\text { banking process as } \\
\text { long as it is not } \\
\text { confirmed }\end{array}$} & Commercial & 137 & 1.2879 & .54815 & \multirow[b]{2}{*}{$\begin{array}{c}- \\
1.704\end{array}$} & \multirow[b]{2}{*}{239} & \multirow[b]{2}{*}{.090} & \multirow[b]{2}{*}{46.46} \\
\hline & Islamic & 104 & 1.4343 & 61117 & & & & \\
\hline \multirow{2}{*}{$\begin{array}{l}\text { Warning customers } \\
\text { to avoid using an } \\
\text { easy password that } \\
\text { facilitates hacking }\end{array}$} & Commercial & 137 & 1.4091 & .60707 & & & & \\
\hline & Islamic & 104 & 1.5486 & .69206 & $\begin{array}{c}- \\
1.441\end{array}$ & 239 & .151 & 50.33 \\
\hline
\end{tabular}




\begin{tabular}{|c|c|c|c|c|c|c|c|c|}
\hline their accounts & & & & & & & & \\
\hline $\begin{array}{c}\text { Restricting account } \\
\text { access after a } \\
\text { number of failed } \\
\text { attempts }\end{array}$ & Islamic & 104 & 1.7943 & .68058 & 5.176 & 239 & .000 & 55.43 \\
\cline { 2 - 7 } & Realizing the \\
$\begin{array}{c}\text { potential of } \\
\text { connecting with } \\
\text { other websites } \\
\text { related to bank's } \\
\text { work }\end{array}$ & Commercial & 137 & 2.0571 & .70885 & & & & \\
\cline { 2 - 6 } & Islamic & 104 & 1.7121 & .75986 & 3.303 & 239 & .001 & 65.40 \\
\hline
\end{tabular}

\section{The previous table shows that:}

- There are various customer attitudes towards the use of the websites in Bahraini banks, they are: realizing the potential of connecting with other websites related to bank's work $(65.40 \%)$, restricting account access after a number of failed attempts (55.43\%), introducing services provided by other banks $(52.96 \%)$, establishing the brand and trade name of the bank among customers (51.03\%), warning customers to avoid using an easy password that facilitates hacking their accounts $(50.33 \%)$, marketing the bank's products and services $(49.76 \%)$, providing banking services to customers $(48.93 \%)$, realizing the potential of electronic purchase $(47.96 \%)$, realizing the potential of canceling any banking process as long as it is not confirmed $(46.46 \%)$, and responding to public inquiries and complaints $(44.93 \%)$.

- There are differences between commercial and Islamic banks according to their attitudes towards the use of the websites in favor of Islamic banks in the following uses: providing banking services to customers, marketing of bank products and services, establishing the brand and trade name of the bank among customers, and restricting account access after a number of failed attempts with arithmetic means of (1.5371), (1.5714), (1.5943), and (1.7943) vs. (1.2879), (1.2879), (1.3636), and (1.3182) for commercial banks. There are differences between the banks under study according to their attitudes towards the use of the websites in favor of commercial banks in realizing the potential of connecting with other websites related to bank's work with an average of (2.0571) vs. (1.7121) for Islamic banks. This is a statistically significant difference; the significance level is lower than (.05). 
Table (8)

Customers' attitudes towards the advantages of the websites of Bahraini banks

\begin{tabular}{|c|c|c|c|c|c|c|c|c|}
\hline Website advantages & Banks & $\mathrm{N}$ & $\begin{array}{l}\text { Arithmetic } \\
\text { Mean }\end{array}$ & $\begin{array}{l}\text { Standard } \\
\text { deviation }\end{array}$ & $\begin{array}{c}\text { T- } \\
\text { Test }\end{array}$ & $\begin{array}{c}\text { Freedom } \\
\text { level }\end{array}$ & $\begin{array}{c}\text { significance } \\
\text { level }\end{array}$ & $\begin{array}{c}\text { Percentage } \\
\text { weight }\end{array}$ \\
\hline \multirow{2}{*}{$\begin{array}{l}\text { The website enables } \\
\text { the bank to access to } \\
\text { a large audience }\end{array}$} & Commercial & 137 & 1.8235 & .75761 & \multirow[b]{2}{*}{.885} & \multirow[b]{2}{*}{239} & \multirow[b]{2}{*}{.377} & \multirow[t]{2}{*}{57.66} \\
\hline & Islamic & 104 & 1.7150 & .64681 & & & & \\
\hline \multirow[b]{2}{*}{$\begin{array}{l}\text { Banks websites are } \\
\text { an appropriate mean } \\
\text { of improving } \\
\text { customer service and } \\
\text { facilitating banking } \\
\text { transactions }\end{array}$} & Commercial & 137 & 2.0588 & 1.09934 & \multirow[b]{2}{*}{-.417} & \multirow[t]{2}{*}{239} & \multirow[b]{2}{*}{.677} & \multirow[t]{2}{*}{70.80} \\
\hline & Islamic & 104 & 2.1353 & .97097 & & & & \\
\hline \multirow{2}{*}{$\begin{array}{l}\text { Banks' websites save } \\
\text { time and effort in } \\
\text { conducting banking } \\
\text { operations }\end{array}$} & Commercial & 137 & 2.0588 & .73613 & \multirow[b]{2}{*}{-.936} & \multirow[t]{2}{*}{239} & \multirow[b]{2}{*}{.350} & \multirow[t]{2}{*}{71.90} \\
\hline & Islamic & 104 & 2.1739 & .65262 & & & & \\
\hline \multirow{2}{*}{$\begin{array}{l}\text { Realizing the } \\
\text { potential of Fast and } \\
\text { low cost banking } \\
\text { transactions }\end{array}$} & Commercial & 137 & 1.2059 & .41043 & \multirow[b]{2}{*}{2.014} & \multirow[t]{2}{*}{239} & \multirow[b]{2}{*}{.049} & \multirow[t]{2}{*}{44.80} \\
\hline & Islamic & 104 & 1.3671 & .54904 & & & & \\
\hline \multirow{2}{*}{$\begin{array}{l}\text { The website gives } \\
\text { free access for } \\
\text { millions of visitors } \\
\text { and internet users } \\
\text { around the world }\end{array}$} & Commercial & 137 & 1.6765 & .47486 & \multirow[b]{2}{*}{1.026} & \multirow[t]{2}{*}{239} & & \multirow[t]{2}{*}{58.63} \\
\hline & Islamic & 104 & 1.7729 & .51355 & & & .306 & \\
\hline \multirow{2}{*}{$\begin{array}{l}\text { The website gives a } \\
\text { clear and complete } \\
\text { idea of using e- } \\
\text { banking services }\end{array}$} & Commercial & 137 & 2.0000 & .60302 & \multirow[b]{2}{*}{1.644} & \multirow[t]{2}{*}{239} & \multirow[b]{2}{*}{.101} & \multirow[t]{2}{*}{72.03} \\
\hline & Islamic & 104 & 2.1884 & .62182 & & & & \\
\hline \multirow[b]{2}{*}{$\begin{array}{c}\text { Realizing the } \\
\text { potential of using } \\
\text { banking services in } \\
\text { the appropriate time } \\
\text { and place for the } \\
\text { customer }\end{array}$} & Commercial & 137 & 1.7059 & .46250 & \multirow[b]{2}{*}{-.264} & \multirow[t]{2}{*}{239} & \multirow[b]{2}{*}{.792} & \multirow[t]{2}{*}{57.53} \\
\hline & Islamic & 104 & 1.7295 & .48697 & & & & \\
\hline There are Staff & Commercial & 137 & 2.0000 & .49237 & & 239 & & 72.86 \\
\hline $\begin{array}{l}\text { members to update } \\
\text { data on the website }\end{array}$ & Islamic & 104 & 2.2174 & .57123 & 2.330 & & .024 & \\
\hline Having a developed & Commercial & 137 & 1.7941 & .47860 & & 239 & & 59.86 \\
\hline $\begin{array}{c}\text { website is a } \\
\text { competitive } \\
\text { advantage in dealing } \\
\text { with customers }\end{array}$ & Islamic & 104 & 1.7971 & .49989 & -.032 & & .974 & \\
\hline The website provides & Commercial & 137 & 1.2647 & .44781 & & & & 42.03 \\
\hline $\begin{array}{l}\text { customers with } \\
\text { information round- } \\
\text { the-clock }\end{array}$ & Islamic & 104 & 1.2609 & .44017 & .047 & 239 & .963 & \\
\hline
\end{tabular}




\section{The previous table shows that:}

- Customers expressed many advantages of using website in Bahraini banks, these advantages include: there are staff members to update data on the website $(72.86 \%)$, the website provides a clear and complete idea of using e-banking services $(72.03 \%)$, the websites of the banks save time and effort in conducting banking operations (71.90\%), banks' websites are a convenient way to improve customer service and facilitate banking transactions $(70.80 \%)$, a developed website has a competitive advantage in dealing with customers $(59.86 \%)$, realizing the potential of using banking services in the appropriate time and place for the customer (58.63\%), the website enables the bank to access to a large audience $(57.66 \%)$, realizing the potential of using banking services in the appropriate time and place for the customer $(57.53 \%)$, realizing the potential of Fast and low cost banking transactions (44.80\%), as well as, the website provides customers with information round-the-clock $(42.03 \%)$.

- There are differences between banks under study according to customers attitudes towards the advantages of the website in Bahraini banks in favor of Islamic banks in realizing the potential of fast and low cost banking transactions and having staff members to update data on the website with an average of (1.3671), and (2.2174) vs. (1.2059), and (2.0000) for commercial banks. This difference is significant statistically; the significance level values are less than (.05).

Table (9)

The extent to which the websites of Bahraini banks meet customers' needs and interests

\begin{tabular}{|c|c|c|c|c|c|c|c|c|c|c|c|c|c|}
\hline \multirow[b]{2}{*}{$\begin{array}{l}\text { The extent } \\
\text { to which } \\
\text { the } \\
\text { websites of } \\
\text { Bahraini } \\
\text { banks meet } \\
\text { customers' } \\
\text { needs and } \\
\text { interests }\end{array}$} & \multicolumn{4}{|c|}{ Commercial banks } & \multicolumn{4}{|c|}{ Islamic banks } & \multicolumn{2}{|c|}{ Total } & \multirow[b]{2}{*}{$\begin{array}{l}\stackrel{\overrightarrow{3}}{\oplus} \\
\stackrel{\leftrightarrow}{\omega}\end{array}$} & \multirow[b]{2}{*}{ 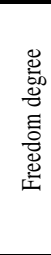 } & \multirow[b]{2}{*}{ 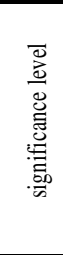 } \\
\hline & $\mathrm{F}$ & $\%$ & 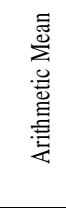 & 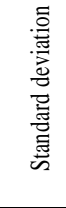 & $\mathrm{F}$ & $\%$ & 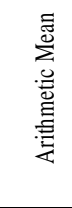 & 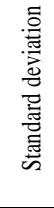 & $\mathrm{F}$ & $\%$ & & & \\
\hline largely & 45 & 32.85 & \multirow{4}{*}{1.868} & \multirow{4}{*}{.7457} & 48 & 46.15 & \multirow{4}{*}{1.740} & \multirow{4}{*}{.775} & 93 & 38.59 & \multirow{4}{*}{1.299} & \multirow{4}{*}{239} & \multirow{4}{*}{.195} \\
\hline Moderately & 68 & 49.64 & & & 35 & 33.65 & & & 103 & 42.74 & & & \\
\hline poorly & 21 & 15.33 & & & 21 & 20.19 & & & 42 & 17.43 & & & \\
\hline $\begin{array}{l}\text { Don't meet } \\
\text { the needs }\end{array}$ & 3 & 2.19 & & & 0 & 0.00 & & & 3 & 1.24 & & & \\
\hline Total & 137 & 100 & & & 104 & & & & 241 & & & & \\
\hline
\end{tabular}




\section{The previous table shows that:}

- $\quad(42.74 \%)$ of customers believed that the banks website met their needs and interests to a medium degree, (38.59\%) saw the banks websites meet their needs and interests to a large extent, and (17.43\%) saw this poorly, while (1.24\%) expressed that the websites under study did not meet their needs and interests .

- There are no statistically significant differences between the commercial and Islamic banks according to the extent to which the websites of Bahraini banks meet customers' needs and interests. The difference is not statistically significant; the value of T-test (1.299) is statistically insignificant at the level of (.195), which is more than (.05).

Table (10)

\section{The duration of Bahraini banks' response to customers'} complaints and inquiries

\begin{tabular}{|c|c|c|c|c|c|c|c|c|c|c|c|c|c|}
\hline \multirow[b]{2}{*}{ Duration } & \multicolumn{4}{|c|}{ Commercial banks } & \multicolumn{4}{|c|}{ Islamic banks } & \multicolumn{2}{|c|}{ Total } & \multirow{2}{*}{$\begin{array}{c}\text { T- } \\
\text { Test }\end{array}$} & \multirow[b]{2}{*}{ 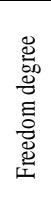 } & \multirow[b]{2}{*}{ 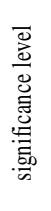 } \\
\hline & $\mathrm{F}$ & $\%$ & 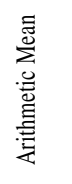 & 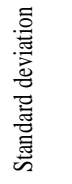 & $\mathrm{F}$ & $\%$ & R. & $\%$ & 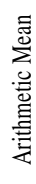 & 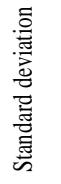 & & & \\
\hline $\begin{array}{l}\text { In the } \\
\text { same } \\
\text { day }\end{array}$ & 6 & 4.38 & \multirow[t]{4}{*}{2.6569} & \multirow[t]{4}{*}{.69067. } & 6 & 5.77 & \multirow[t]{4}{*}{2.5192} & \multirow[t]{4}{*}{.68238 } & 12 & 4.98 & \multirow[t]{4}{*}{1.541} & \multirow[t]{4}{*}{139} & \multirow[t]{4}{*}{.125} \\
\hline $\begin{array}{c}\text { Within a } \\
\text { week }\end{array}$ & 46 & 33.58 & & & 43 & 41.35 & & & 89 & 36.93 & & & \\
\hline $\begin{array}{l}\text { Within } \\
\text { two } \\
\text { weeks }\end{array}$ & 74 & 54.01 & & & 50 & 48.08 & & & 124 & 51.45 & & & \\
\hline $\begin{array}{c}\text { Within a } \\
\text { month }\end{array}$ & 11 & 8.03 & & & 5 & 4.81 & & & 16 & 6.64 & & & \\
\hline Total & 137 & 100 & & & 100 & & & & 241 & & & & \\
\hline
\end{tabular}

\section{The previous table shows that:}

- $(51.45 \%)$ of customers saw that the websites of the banks responded to their inquiries within two weeks, $(36.93 \%)$ said that these inquiries were responded during the week , and (6.64\%) said that these inquiries were responded during the same month $(4.98 \%)$. 
- There are no statistically significant differences between commercial and Islamic banks according to the duration in which Bahraini banks responded to customers' complaints and inquiries. The difference is not statistically significant. The value of T-test (1.541) is statistically insignificant at a significant level of (.125), which is greater than the $(.05)$.

Table (11)

The effectiveness of hyperlinks provided by the Bahraini banks' websites

\begin{tabular}{|c|c|c|c|c|c|c|c|c|c|c|c|c|c|}
\hline \multirow[b]{2}{*}{$\begin{array}{c}\text { The extent to } \\
\text { which } \\
\text { Bahraini } \\
\text { banks } \\
\text { websites } \\
\text { provide } \\
\text { hyperlinks }\end{array}$} & \multicolumn{4}{|c|}{ Commercial banks } & \multicolumn{4}{|c|}{ Islamic banks } & \multicolumn{2}{|c|}{ Total } & \multirow{2}{*}{$\begin{array}{l}\text { T- } \\
\text { Test }\end{array}$} & \multirow[b]{2}{*}{ 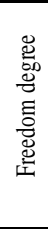 } & \multirow[b]{2}{*}{ 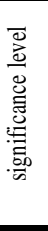 } \\
\hline & $\mathrm{F}$ & $\%$ & $\mathrm{~F}$ & $\%$ & $\mathrm{~F}$ & $\%$ & $\mathrm{~F}$ & $\%$ & F & $\%$ & & & \\
\hline $\begin{array}{l}\text { Allows you } \\
\text { to use all } \\
\text { hyperlinks } \\
\text { and access } \\
\text { other related } \\
\text { sites }\end{array}$ & 98 & 71.53 & 1.284 & .4529 & 87 & 83.65 & 1.163 & .3715 & 185 & 76.6 & 2.220 & 239 & .027 \\
\hline Do not allow & 39 & 28.47 & & & 17 & 16.35 & & & 56 & 23.24 & & & \\
\hline Total & 137 & 100 & & & 104 & & & & 241 & & & & \\
\hline
\end{tabular}

The previous table shows that:

- $(76.6 \%)$ of customers believed that banks' websites allowed the use of all hyperlinks and access to other related sites. In contrast, $(23.24 \%)$ saw that these sites did not allow the use of all hyperlinks and access to other related sites.

- There are statistically significant differences between commercial and Islamic banks according to the extent to which Bahraini banks websites provided hyperlinks in favor of commercial banks with an average of (1.284) compared to (1.163) for Islamic banks. The difference is statistically significant; the value of T-test (2.220) is statistically significant at a significance level of (.195), which is less than (.05). 
Table (12)

Customers' interaction with Bahraini banks websites

\begin{tabular}{|c|c|c|c|c|c|c|c|c|}
\hline \multirow[t]{2}{*}{ Interaction } & \multicolumn{2}{|c|}{ Commercial banks } & \multicolumn{2}{|c|}{ Islamic banks } & \multicolumn{2}{|c|}{ Total } & \multirow[t]{2}{*}{ Z-Test } & \multirow[t]{2}{*}{ significance level } \\
\hline & $\mathrm{F}$ & $\%$ & $\mathrm{~F}$ & $\%$ & $\mathrm{~F}$ & $\%$ & & \\
\hline Downloading & 33 & 24.09 & 16 & 15.38 & 49 & 20.33 & 1.66 & Significant \\
\hline Sending E-mail & 102 & 74.45 & 98 & 94.23 & 200 & 82.99 & 4.05 & Significant \\
\hline $\begin{array}{l}\text { Printing data provided } \\
\text { on the site }\end{array}$ & 21 & 15.33 & 29 & 27.88 & 50 & 20.75 & 2.38 & Non significant \\
\hline $\begin{array}{c}\text { Using links to } \\
\text { additional information }\end{array}$ & 92 & 67.15 & 77 & 74.04 & 169 & 70.12 & 1.16 & Significant \\
\hline $\begin{array}{l}\text { Sharing topics via } \\
\text { social media }\end{array}$ & 32 & 23.36 & 24 & 23.08 & 56 & 23.24 & .05 & Significant \\
\hline direct chatting & 7 & 5.11 & 4 & 3.85 & 11 & 4.56 & .47 & Non significant \\
\hline Total of respondents & & & & & & & & \\
\hline
\end{tabular}

The previous table shows that:

- The e-mail ranked first in customers interaction with the websites of Bahraini banks (82.99\%), then links to additional information (70.12\%), the participation of topics via social networking sites ranked third $(23.24 \%)$, followed by printing data provided on the site $(20.75 \%)$, then downloading files $(20.33 \%)$, and direct chatting came in last $(4.56 \%)$.

- There are significant differences between commercial and Islamic banks according to the customer interaction with Bahraini banks websites in sending an e-mail and printing data from the site by (94.23\%) and (27.88\%) for Islamic banks vs. (74.45\%) and (15.33) for commercial banks. This is a relative significant difference. Ztest values are (4.05) and (2.38), which are higher than (2.58) and (1.96); this indicates a significant correlation between the two variables with (99\%) and (95\%) confidence levels respectively.

Table (13)

The websites' elements of attraction of Bahraini banks

\begin{tabular}{|c|c|c|c|c|c|c|c|c|}
\hline \multirow{2}{*}{ Elements of attraction } & \multicolumn{2}{|c|}{ Commercial banks } & \multicolumn{2}{|c|}{ Islamic banks } & \multicolumn{2}{|c|}{ Total } & Z-Test & significance level \\
\cline { 2 - 10 } & $\mathrm{F}$ & $\%$ & $\mathrm{~F}$ & $\%$ & $\mathrm{~F}$ & $\%$ & & Significant \\
\hline The content & 84 & 61.31 & 65 & 62.50 & 99 & 41.08 & 5.59 & Significant \\
\hline Site's attractive colors & 71 & 51.82 & 81 & 77.88 & 152 & 63.07 & 4.15 & Significant \\
\hline Site's modern design & 51 & 37.23 & 45 & 43.27 & 96 & 39.83 & .95 & Significant \\
\hline $\begin{array}{c}\text { Ability to interact with } \\
\text { customers }\end{array}$ & 58 & 42.34 & 28 & 26.92 & 61 & 25.31 & 2.47 & Non significant \\
\hline $\begin{array}{c}\text { Ability to interact with } \\
\text { senior management }\end{array}$ & 25 & 18.25 & 48 & 46.15 & 73 & 30.29 & 4.67 & \\
\hline $\begin{array}{c}\text { Providing links on the } \\
\text { site help to identify the } \\
\text { various services } \\
\text { offered by other banks' } \\
\text { sites }\end{array}$ & 85 & 62.04 & 56 & 53.85 & 141 & 58.51 & 1.28 & \\
\hline \begin{tabular}{c} 
Total of respondents \\
\hline
\end{tabular} & 137 & & 104 & & 241 & & \\
\hline
\end{tabular}




\section{The previous table showed that:}

-The attractive colors of the site ranked first in websites' elements of attraction (63.07\%), followed by providing links on the site to identify various services offered by other banks' sites $(58.51 \%)$, the content had the third highest rate (41.08), then the modern design $(39.83 \%)$, and the ability to interact with customers came in last $(25.31 \%)$.

-There are statistically significant differences between the banks under study according to elements for attracting customers to their websites in favor of commercial banks in the possibility of interacting with the employees by (42.34\%) compared to (26.92\%) for Islamic banks. This is a relative significant difference; $\mathrm{Z}$ value is greater than (1.96), which indicates that there is a relationship between the two variables with a $(95 \%)$ confidence level.

-Also, there are statistically significant differences between the banks under study according to elements of attraction in favor of Islamic banks in: content, attractive colors and ability to interact with senior management by $(62.50 \%),(77.88 \%)$, and $(46.15 \%)$ versus $(46.15 \%),(51.82 \%)$, and $(18.25 \%)$ for commercial ones. This is a relative significant difference; the value of Z-test is greater than (2.58), which indicates a significant correlation between the two variables with a (99\%) confidence level.

Table (14)

weaknesses of the websites of Bahraini banks

\begin{tabular}{|c|c|c|c|c|c|c|c|c|}
\hline \multirow[b]{2}{*}{ Weaknesses } & \multicolumn{2}{|c|}{ Commercial banks } & \multicolumn{2}{|c|}{ Islamic banks } & \multicolumn{2}{|c|}{ Total } & \multirow{2}{*}{$\begin{array}{c}\text { Z- } \\
\text { Tes } \\
\mathrm{t}\end{array}$} & \multirow[b]{2}{*}{$\begin{array}{l}\text { significance } \\
\text { level }\end{array}$} \\
\hline & $\mathrm{F}$ & $\%$ & $\mathrm{~F}$ & $\%$ & $\mathrm{~F}$ & $\%$ & & \\
\hline Not revamping the website & 21 & 15.33 & 15 & 14.42 & 36 & 14.94 & .20 & Non significant \\
\hline $\begin{array}{l}\text { Not providing opportunities for } \\
\text { communication with the management }\end{array}$ & 25 & 18.25 & 21 & 20.19 & 46 & 19.09 & .38 & Non significant \\
\hline Lack of diversity in content provided & 27 & 19.71 & 23 & 22.12 & 50 & 20.75 & .46 & Non significant \\
\hline Not renewing the displayed images & 24 & 17.52 & 18 & 17.31 & 42 & 17.43 & .04 & Non significant \\
\hline Delaying site updates & 30 & 21.90 & 26 & 25.00 & 56 & 23.24 & .56 & Non significant \\
\hline Lack of links & 29 & 21.17 & 14 & 13.46 & 43 & 17.84 & $\begin{array}{c}1.5 \\
5\end{array}$ & Non significant \\
\hline Total of respondents & & 37 & & 104 & & & & \\
\hline
\end{tabular}




\section{The previous table shows that:}

- The delay in updating the sites ranked first in weaknesses of the websites of Bahraini banks (23.24\%), then the lack of diversity in the content $(20.75 \%)$, not providing opportunities for communication with the management ranked third (19.09\%), then the lack of links $(17.43 \%)$, and the fifth place is occupied by not revamping the website $(14.09 \%)$.

- There are no statistically significant differences between commercial and Islamic banks according to the weaknesses of the websites. The difference is relatively non-significant; the values of Z-test are less than (1.96) which indicates that there is a differential relationship between the two variables with a $(95 \%)$ confidence level.

\section{Study Hypothesis:}

The researcher determined specific, clear, and testable proposition and predictive statements about the possible outcome of his research study. These hypotheses have been tested as follows:

The First Hypothesis: There is a statistically significant relationship between the extent to which the public relations departments in Bahraini banks updated the banks' websites and customers' attitudes towards the importance of these websites.

To test the validity of this hypothesis, the researcher used the Pearson correlation coefficient.

\section{Table (15)}

Pearson correlation coefficient between the extent to which the public relations departments in Bahraini banks updated the banks' websites and customers' attitudes towards the importance of these websites

\begin{tabular}{|c|c|c|}
\hline $\begin{array}{c}\text { Pearson correlation } \\
\text { coefficient value }\end{array}$ & $\mathrm{N}$ & Significance level \\
\hline$* * 0.559$ & 241 & $\mathbf{. 0 0 1}$ \\
\hline
\end{tabular}

Total of sample members $=\mathrm{N} \quad$ Significance level $=\mathrm{P}$ Pearson correlation coefficient $=\mathbf{R}$ 
- The results of the previous table show a correlation between the extent to which the public relations departments in Bahraini banks updated the banks' websites and customers' attitudes towards the importance of these websites. The Pearson correlation coefficient between them is (0.559), which is statistically significant at a level of (0.01). This indicates that the more public relations departments update banks website, the more customers recognize the importance of these sites in providing information and services performed by the bank.

The second hypothesis: There is a statistically significant relationship between the weaknesses of the websites of Bahraini banks' and customers' attitudes towards the importance of these websites.

To test the validity of this hypothesis, the researcher used the Pearson correlation coefficient.

\section{Table (16):}

Pearson correlation coefficient between the weaknesses of the Bahraini banks' websites and customers' attitudes towards the importance of these websites

\begin{tabular}{|c|c|c|}
\hline $\begin{array}{c}\text { Pearson correlation } \\
\text { coefficient value }\end{array}$ & $\mathrm{N}$ & Significance level \\
\hline $\mathbf{- 0 . 4 1 2}$ & $\mathbf{2 4 1}$ & $\mathbf{0 . 0 0}$ \\
\hline Total of sample members=N \\
correlation coefficient=R
\end{tabular}

- The results of the previous table indicate that there is a positive correlation between the weaknesses of the Bahraini banks' websites and customers' attitudes towards the importance of these websites. The value of the Pearson correlation coefficient between them is $(-0.412)$, which is significant at a level of $(0.000)$. So, the more respondents recognize the weaknesses of Bahraini banks website, the more negative attitudes they have towards the services performed by the site.

The third hypothesis: There is a statistically significant relationship between the extent to which Bahraini banks' managements update 
banks websites and customers attitudes towards the importance of these websites.

To test the validity of this hypothesis, the researcher used the Pearson correlation coefficient.

\section{Table (17)}

Pearson's correlation coefficient between the extent to which Bahraini banks' managements update banks; websites and customers; attitudes towards the importance of these websites

\begin{tabular}{|c|c|c|}
\hline $\begin{array}{c}\text { Pearson correlation } \\
\text { coefficient value }\end{array}$ & Number & Significance level \\
\hline $\mathbf{0 . 6 5 4}$ & 241 & $\mathbf{0 . 0 0 1}$ \\
\hline Total of sample members=N & $\begin{array}{c}\text { Significance level }=\mathrm{P} \quad \text { Pearson } \\
\text { correlation coefficient }=\mathrm{R}\end{array}$
\end{tabular}

- The results of the previous table show a positive correlation between the extent to which Bahraini banks' managements update banks; websites and customers; attitudes towards the importance of these websites. The Pearson correlation coefficient between them is 0.654. This is significant at a level of (0.001). So, the more the respondents see the website is weak, the more negative attitudes they have towards the services performed by the site.

\section{The most important results of the study:}

1- Bahraini commercial and Islamic banks relied on e-mail and SMS in communicating customers. The study finds differences in these two ways of communicating between the banks under study.

2- Bahraini banks did not care about updating their websites permanently. Commercial banks were interested in updating their websites compared to Islamic ones.

3- Bahraini banks were concerned with contents regarding activities provided by the bank and the leading figures, how to conduct business transactions, investment opportunities and savings, periodical and annual reports issued by the bank and the bank phone numbers and e-mail. The study shows that commercial banks was superior to Islamic ones in concerning with 
information about the bank's services, the bank' role in society, the bank's leading figures, and investment opportunities.

4- Commercial banks were superior to Islamic banks in using e-mail to communicate customers, to provide them with the most important information and news about the bank, to receive messages, feedback, suggestions and inquiries, then responding to them quickly. Thus facilitating communication between the bank and customers, enabling the customers to evaluate banks' programs and activities, responding to harmful rumors, explaining the bank's policy to customers, and getting customers to participate in some events held by the bank.

5- There were various uses of the internet in commercial banks. These banks used e-mail service to communicate customers. The bank's management benefited from the file transfer protocol (FTP) in sending customers circulars. The bank's management took advantage of the Internet in preparing and organizing seminars, the internet reduced the time and effort to accomplish the bank's work. Also, the bank's management encouraged holding training courses for employees to promote using of internet in dealing with customers.

6- Commercial banks used the internet in saving time and effort to accomplish the work of public relations, while the internet had a negative effect on personal interactions within the bank. Islamic banks were superior to commercial ones in using e-mail service to communicate with customers, and in using the internet in holding seminars, and lectures.

7- The public believed that Bahraini banks websites play an important role in the society, because they were a means of identifying the services provided by the bank, and collecting information about competing banks, an easy way to enter the local markets, a means to develop electronic transactions between the bank and its customers, and a way to expand the provision of banking services.

8- The customers' attitudes toward the uses of Bahraini banks websites were as follows: realizing the potential of connecting with other websites related to bank's work, restricting account 
access after a number of failed attempts, introducing services provided by other banks, establishing the brand and trade name of the bank among customers, warning customers to avoid using an easy password that facilitates hacking their accounts, marketing the bank's products and services, providing banking services to customers, realizing the potential of electronic purchase, realizing the potential of canceling any banking process as long as it has not been confirmed and responding to public inquiries and complaints.

9- The study reveals differences between commercial and Islamic banks according to their attitudes towards the use of the websites in favor of Islamic banks in the following uses: providing banking services to customers, marketing of bank products and services, establishing the brand and trade name of the bank among customers, restricting account access after a number of failed attempts. Also, there are differences between the banks under study according to their attitudes towards the use of the websites in favor of commercial banks in realizing the potential of connecting with other websites related to bank's work.

10-Customers expressed many advantages of using website in Bahraini banks, these advantages include: There are Staff members to update data on the website, the website provide a clear and complete idea of using e-banking services. The websites of the banks save time and effort in conducting banking operations, bank websites are a convenient way to improve customer service and facilitate banking transactions, a developed website has a competitive advantage in dealing with customers. Also, realizing the potential of using banking services in the appropriate time and place for the customer, the website enables the bank to access to a large audience, realizing the potential of using banking services in the appropriate time and place for the customer, realizing the potential of Fast and low cost banking transactions, and the website provides customers with information round-the-clock.

11- Customers interacted with the Bahraini banks' websites through the e-mail, links to additional information, the participation of topics via social networking sites, followed by printing data 
provided on the site, then downloading files, and direct chatting. The study shows there are significant differences between commercial and Islamic banks according to the customer interaction with the websites of Bahraini banks in sending an email and printing data from the site.

12- There are many elements that attracted customers to the Bahraini banks; websites; these elements include attractive colors of the site, providing links on the site to identify various services offered by other banks' sites, the content, then the modern design, and the ability to interact with customers. The study shows that there are statistically significant differences between the banks under study according to elements for attracting customers to their websites in favor of commercial banks in the possibility of interacting with the employees, and in favor of Islamic banks in: content, attractive colors and ability to interact with senior management.

13- Despite Bahraini banks concerned with their websites, there were some weaknesses of them. These included the delay in updating the sites, then the lack of diversity in the content, not providing opportunities for communication with the management, then the lack of links, and not revamping the website. The study shows that there are no statistically significant differences between commercial and Islamic banks according to the weaknesses of these websites.

14- The results of testing hypothesis confirmed a correlation between the extent to which the public relations departments in Bahraini banks updated the banks' websites and customers' attitudes towards the importance of these websites, a positive correlation between the weaknesses of the Bahraini banks' websites and customers' attitudes towards the importance of these websites, and a positive correlation between the extent to which Bahraini banks' managements update banks' websites and customers' attitudes towards the importance of these websites.

\section{Study Recommendations}

In light of the study results, the researcher determines the following recommendations: 
1- Raising the Bahraini banks' awareness of the importance of the websites in shaping the mental image of the banks among customers, by meeting their needs and interests and responding quickly to their inquiries and complaints.

2- Caring about the websites design and content due to its role in facilitating the movement of banking transactions and interaction between the management of the bank and its customers.

3- Supporting e-mail service and its use, and strengthening the technical structure and electronic devices in banks, to overcome the problems of weak internet services.

4- Supporting the use of other communication means, such as personal communication, press releases, newsletters and SMS via mobile phone to strengthen the interactive communication between public relations departments and customers.

5- The need to train officials of websites in banks on the skills of personal treatment and personal communication to solve customs" problems and responding to their inquiries quickly.

6- Developing the skills of public relations officers in using the internet. 


\section{References:}

1- Jaka, Lindič (2006), How Do Corporations Use Internet for Public Relations? 19th Belde Conference eValues Bled, Sloveniam, P.2.

2- Reda Hani Abdel Raouf (2018), The Use of Interactive Communication in the Management of the Organization's Relationships with Customers, A Comparative Study between the Traditional and Electronic Communication of a Sample of Egyptian Banks and Foreign Banks Operating in Egypt, Unpublished PhD Thesis, Cairo University, Faculty of Information.

3- Ruaa Ali Yousef Ahmed (2017), The Role of Public Relations in Improving Customer Attitudes towards Banking Services, Unpublished Master Thesis, Sudan University of Science and Technology, College of Graduate Studies.

4- Mohammed Shehadeh Ibrahim Al-Enezi (2016), The Effect of Customer Relationship Management on Achieving Loyalty to Commercial Bank customers: A Field Study of Commercial Banks in Zarqa / Jordan, Unpublished Master Thesis, Zarqa University, Graduate School.

5- Farahat Mohamed Khalil (2016), The Impact of ICT on the Professional Practice of Public Relations in Libyan Banks, An Applied Study on the National Commercial, Development and Commercial Bank, Unpublished PhD Thesis, Mansoura University, Faculty of Arts.

6- Firas Muslim Abuqaoud \& Imad Ahmed Aldheimat (2016), The Effect of EMarketing in Achieving Customer Satisfaction of Banks: Case Study: Commercial Bank of Jordan, Studies, Administrative Sciences, Volume 43, No. 1, pp. 203-220.

7- Saud Mohammed Al-Mahamid (2016), The readiness of employees in the perceived quality of electronic business systems services, user satisfaction and intention to use: a field study in banks listed in the Amman Financial Market, Studies, Administrative Sciences, Volume 41, No. 1, pp. 1-20.

8- Eman Shukri Abdel Hamid Hijazi (2013), The role of web sites design of Egyptian Institutions in support of the communication function of these institutions: Analytical and field study, Unpublished PhD Thesis, Mansoura University: Faculty of Arts.

9- Ahmed Farouk Radwan(2012), Crisis Communications Department through the organization's website: A study on the car recall crisis for Toyota during the year, Arab Journal of Information and Communication, Riyadh, King Saud University, College of Arts, Saudi Society for Information and Communication, No. 8.

10- William, Genilo, Jude; Marium , Akther; Chowdhury, Ahmed, Imtia (2011),A Survey of Public Relations Practice in Bangladesh, Media Asia, Vol. 38 Issue 4.5. 
11- Hanan Farouk Jenuid (2010), The Role of Websites in Achieving Communication Objectives of the Organization, Analytical Study of the Websites of Public and Private Universities in Egypt and the UAE, Journal of Journalism Research, Cairo University: Faculty of Information, Issue 3, April-June, July-September 2010.

12- Deepti , Bhargava (2010), The use of Internet in public relations and its impact on the practice: A New Zealand perspective. Masters in Communication Studies (MCS). School of Communications Studies, Faculty of Design and Creative Technologies.

13- Khairat Moawad Mohammed Ayad (2009), Public Relations Media Responsibility through the Internet, A Study on the Profit and Nonprofit Organizations in Egypt and the UAE, Journal of the University of Sharjah for Humanities and Social Sciences, Vol. 6 No. 3.

14- Hassan Bin Omar Basfar (2008), Communication and Investors in the Saudi stock market: a survey study on a sample of the city of Jeddah, King Abdulaziz University, Faculty of Arts and Humanities, Research Center.

15- Kirat Mohamed (2007),Virtual Public Relations In The United Arab Emirates, A Study Of Pr Department Use Of Internet, International Conference New Media Technology For A New World, Bahrain University, 7-9 April,2009, P110-136.

16- Sharifa Rahma Allah Sulaiman (2006), The role of communication and public relations in e-government, case study on the Emirate of Dubai, Unpublished Master Thesis, Cairo University, Faculty of Information.

17- Ahmed Farouk Radwan (2006), The Role of Websites for Arab Profit Organizations in Building Relationship with the Public: A Study in Communication Functions of Public Relations, The Twelfth Scientific Conference, Media and Modernization of Arab Societies "2-4 May 2006, Cairo University: Faculty of Information.

18- Marieke mSchurink (2005), Effective Internet Public Relations Activities. Hogeschool van Utrecht, Faculty of Communication and Journalism Integrated Communication Management.

19- Earl, Babbie, R. (1990), Survey research methods, 2nd ed. - Belmont, Calif: Wadsworth Pub. Co, ISBN 0534126723, p p 395.

20- Mohamed Abdel Hamid (1992), Journalism Research, Cairo, World of Books, pp. 93-94.

21- Bassel Mohammed Said Al-Abedah (2005), Skills of Design and Implementation of Scientific Research and Studies and Statistical Analysis Using SPSS Program, 1, Kuwait, Scientific Publishing Council, p. 84.

22- Mohamed Abdel Hamid (2000), Scientific Research in Media Studies, 1, Cairo, World of Books, p.159. 
23- Ghareeb Mohamed Sayed (2007), The Design and Implementation of Social Research, Cairo, Dar Al-Fikr Al-Arabi, p. 257.

24- Ahmed Bader (1989), The Origins of Scientific Research and Its Methods, Cairo University, Dar al-Ma'arif, p. 273.

25- Mofawed Awad Al-Enezi (2006), Public Relations in Saudi Commercial Banks, A Study in Management Attitudes and Actual Practice, Unpublished Master Thesis, King Saud University, Faculty of Arts, p16.

26- Nasser Al-Ghareeb (2000), Islamic Banking Assets and Operating Issues, Cairo, Abelo Library, 2000, pp. 47-52.

27- Hamad Mubarak Salem (2014), The economic expert dr. Farid Hadi in an interview with the press about the reality and future of the sector: Islamic banking in the Kingdom of Bahrain between reality and hope, Alnbaa Newspaper, Issue 301, 16 April 2024.

28- Samir Ramadan Al-Sheikh (1994),Organizational Development in Islamic Banks, Unpublished PhD Thesis, Assiut University, Sohag Faculty of Commerce, pp. 35-36.

29- Bahrain Services Directory: available at: http://www.dalilbh.net/s-1-14-1$\underline{1 . h t m l}$ 